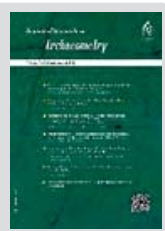

Original Paper

\title{
Elemental Composition of Glass Artifacts excavated from Takht-e Suleiman World CrossMark Heritage Site and Ardabil Ancient Sites in Northwestern Iran by Micro-PIXE
}

\author{
Davoud Agha-Aligol ${ }^{*}$, Hassan Yousefi ${ }^{2}$, Mahmoud Moradi ${ }^{3}$ \\ 1. Nuclear Science and Technology Research Institute, Physics and Accelerators Research School, Van \\ de Graaff Laboratory, Tehran, IRAN \\ 2. PhD of Archeology, Expert of Ardabil Cultural Heritage Office, Ardabil, IRAN \\ 3. Nuclear Science and Technology Research Institute, Physics and Accelerators Research School, Van \\ de Graaff Laboratory, Tehran, IRAN
}

Received: 17/03/2021

Accepted: 22/06/2021

\begin{abstract}
This paper reports and discusses elemental composition results obtained from analysis of 36 glass fragments discovered from the Takht-e Suleiman World Heritage Site and Ardabil historical sites in northwestern Iran. The analyzed samples dating back to Sassanian/Islamic period. The glass objects in this study include decorative objects such as bracelet, pieces of vessels, and indefinites form such as chunk and raw materials, which are in different colors of light and dark green, emerald green, white, purple, turquoise, brown and black. Elemental analysis of these samples was performed using micro-PIXE technique in Van de Graaff Laboratory in the Nuclear Science \& Technology Research Institute in Tehran, Iran. By micro-PIXE analysis, the major and minor elements of these glasses were measured. Elements measured in all 36 samples include: sodium oxide $\left(\mathrm{Na}_{2} \mathrm{O}\right)$, magnesium oxide $(\mathrm{MgO})$, aluminum oxide $\left(\mathrm{Al}_{2} \mathrm{O}_{3}\right)$, silicon oxide $\left(\mathrm{SiO}_{2}\right)$, phosphorus oxide $\left(\mathrm{P}_{2} \mathrm{O}_{5}\right)$, Sulfur oxide $\left(\mathrm{SO}_{3}\right)$, chlorine $(\mathrm{Cl})$, potassium oxide $\left(\mathrm{K}_{2} \mathrm{O}\right)$, calcium oxide $(\mathrm{CaO})$, titanium oxide $\left(\mathrm{TiO}_{2}\right)$, manganese oxide $(\mathrm{MnO})$ and iron oxide $\left(\mathrm{Fe}_{2} \mathrm{O}_{3}\right)$. Chromium oxide $\left(\mathrm{Cr}_{2} \mathrm{O} 3\right)$, cobalt oxide $(\mathrm{CoO})$, copper oxide $\left(\mathrm{Cu}_{2} \mathrm{O}\right)$, zinc oxide $(\mathrm{ZnO})$, strontium oxide $(\mathrm{SrO})$ and lead oxide $(\mathrm{PbO})$ were also measured in a number of samples. In addition, one sample contains barium oxide $(\mathrm{BaO})$ and two samples contain tin oxide $\left(\mathrm{SnO}_{2}\right)$ and arsenic oxide $\left(\mathrm{As}_{2} \mathrm{O}_{5}\right)$. According to elemental analysis results, the important questions in technology and manufacturing technique, determining the raw materials used in manufacturing, determining the type of glass as well as investigation of trade and exchange of raw materials about analyzed glasses are answered. Furthermore, to investigate the provenance of artifacts and to determine the differences in the elemental compositions of glass excavated from Takht-e Suleiman World Heritage Site and Ardabil historical sites, our elemental composition results have been combined and compared with the reported results from other sites of the Eastern Mediterranean countries, such as Syria, Egypt, Palestine, Lebanon and neighboring countries of Iran such as Iraq.
\end{abstract}

Keywords: Micro-PIXE, Elemental analysis, Historical glass, Takht-e Suleiman World Heritage, Ardabil historical sites

*Corresponding Author:

Copyright $@ 2021$, the Authors / This open-access article is published under the terms of the Creative Commons Attribution-NonCommercial 4.0 International License which permits Share (copy and redistribute the material in any medium or format) and Adapt (remix, transform, and build upon the material) under the Attribution-NonCommercial terms 


\section{Introduction}

Literature survey on early Islamic and pre-Islamic glass objects especially sasanian glasses indicates

that there are only few studies on a limited number of early Islamic and sasanian glasses from Iran. However, researchers and archaeologists have always been interested in the elemental analysis of ancient glasses, because investigation of the elemental composition of glass objects provide a lot of information about the manufacturing technique, the determination of the raw materials and the colorant agants were used to create different colors. In this study, 36 samples of glass objects from the Takht-e Suleiman World Heritage Site and Ardabil historical sites have been selected to analyze by micro-PIXE techniques.

\section{Materials and Methods}

Glass fragments discovered from the Takht-e Suleiman World Heritage Site and Ardabil historical sites in northwestern Iran were analyzed. The analyzed samples dated to Sassanian / Islamic period. The glass objects in this study include decorative objects such as bracelet, pieces of vessels, and indefinites form such as chunk and raw materials, which are in different colors.

The general definition of micro-PIXE is "Particle Induced X-ray Emission in micron scale", although this is often used to "proton-induced X-ray emission". The micro-PIXE technique is carried out by bombarding the samples in a vacuum chamber using a beam of high-energy particles $(2-3 \mathrm{MeV})$. As a result of the particle bombardment, X-rays of a characteristic energy of the element are emitted. The energy of X-rays for each element is specific and it can be used to detect the elements that present in the sample. Also, the number of X-ray with specific energy can be used to determine the concentration of the elements within the sample. With this technique, one can measure the concentration of $\mathrm{Na}$ (sodium) to $\mathrm{U}$ (uranium) with an accuracy of parts per million (ppm). In the present paper, the micro-PIXE analysis was performed with Oxford Instruments microprobe system using the $3 \mathrm{MV}$ Van de Graaff accelerators in the Nuclear Science \& Technology Research Institute in Atomic Energy Organization of Iran. The samples were analyzed in a vacuum chamber using a beam of $2.2 \mathrm{MeV}$ protons focused to a diameter less than $10 \mu \mathrm{m}$. The beam current was in the range of 30 to $50 \mathrm{pA}$. Characteristic X-rays were detected using a $\mathrm{Si}(\mathrm{Li})$ detector with an active area of $60 \mathrm{~mm}^{2}$ positioned at an angle of $135^{\circ}$ relative to the incident beam direction and with an energy resolution of $150 \mathrm{eV}$ for $\mathrm{Fe}-\mathrm{K}_{\alpha}$. Samples were scanned over a maximum area of $2.5 \mathrm{~mm} \times 2.5 \mathrm{~mm}$ and digitized signals were recorded in event by event mode (listmode) using the OM-DAQ data acquisition system and the X-ray spectra were processed using GUPIXWIN package to obtain the elemental composition of the samples. In order to check the validity of the micro-PIXE analysis and to evaluate the accuracy of our measurements, Corning glasses A, B, C and D as appropriate glass standard samples were analyzed in the same conditions and then the obtained results were compared to the reported results for these standard samples.

\section{Results and discutions}

The results obtained from this study show that the analyzed glass from these areas are classified into 6 different groups based on the raw materials used in manufacturing. These classifications include 2 different groups of plant ash-soda-lime-silica glass (29 samples), one group of natron glass type (3 samples), one group of soda-lead-lime-silica glass (2 samples), one group of lead- bariumsilica glass (one sample) and a group of potash-lime-silica glass (one sample). The two plant ashsoda-lime-silica glass groups which was named Plant-ash A and Plant-ash B are completely separated based on the concentration of sodium oxide. In the Plant-ash A group, the weight percentage of sodium oxide varies between 17 to $20 \mathrm{wt} . \%$, while in the Plant-ash B group, the weight percentage of sodium oxide varies between 13\% t o16wt. $\%$. In addition, based on the concentrations of $\mathrm{Al}_{2} \mathrm{O}_{3}, \mathrm{SiO}_{2} \mathrm{TiO}_{2}$ and $\mathrm{Fe}_{2} \mathrm{O}_{3}$ different sources of silica can be considered for two different groups of plant ash-soda-lime-silica glass analyzed from Takht-e Suleiman. Moreover, according to elemental composition of glass objects it can be concluded that to make various color glass, different transition elements such iron, copper, manganese and cobalt oxide are used. 


\section{Conclution}

The elemental composition of glasses shows that most glasses obtained in Takht-e Suleiman World Heritage Site and Ardabil historical sites are plant ash-silica-soda-lime glass type that the ashes obtained from halophytic plants are considered as supplying source of fluxe. Moreover, the results of elemental analysis of these glasses confirm that the origin and place of production of some glasses that are belong to natron group and $\mathrm{Pb}-\mathrm{Ba}$ group is non-local and probably were imported from other areas such as Egypt or the eastern Mediterranean Sea regions and China through the trade and

exchange of glass products. In addition, the elemental composition of these samples show that $\mathrm{Fe}_{2} \mathrm{O}_{3} \mathrm{CoO}$ and $\mathrm{Cu}_{2} \mathrm{O}$ are the colorant agents and $\mathrm{MnO}$ has been used as a decolorant element in the samples. 


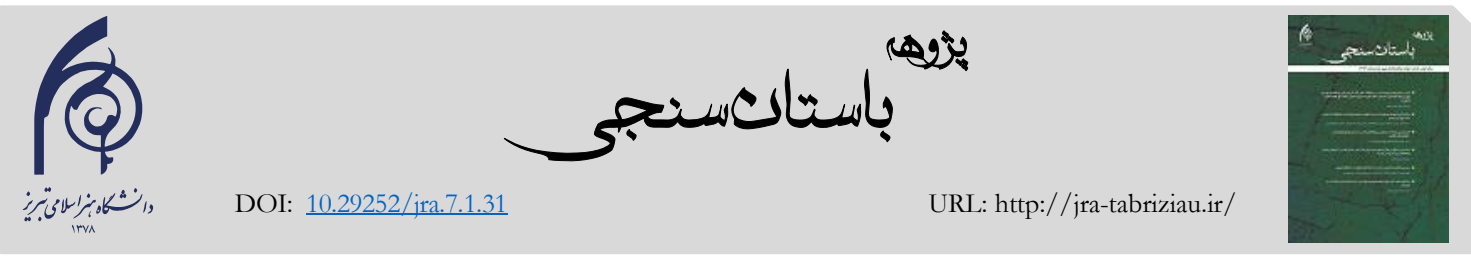

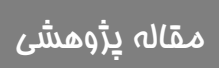

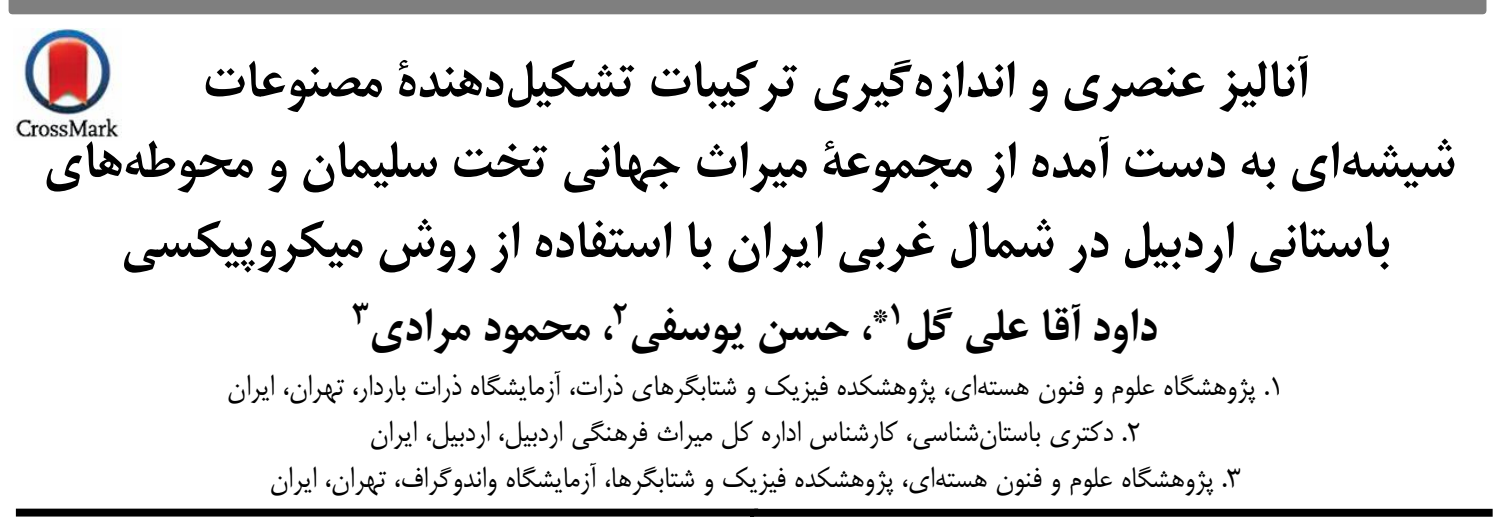

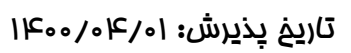

تاريخ دريافت:

جكيده

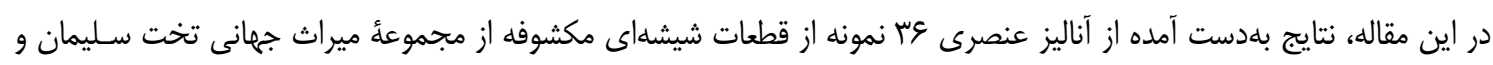

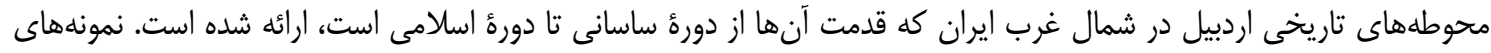

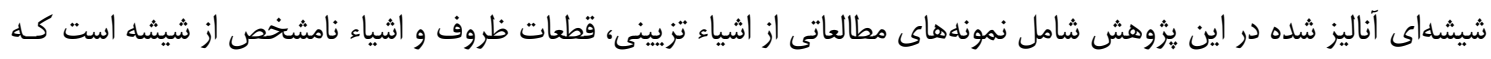

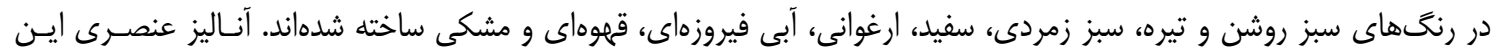

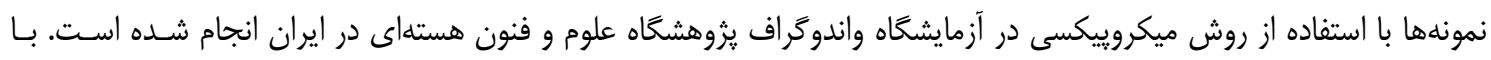

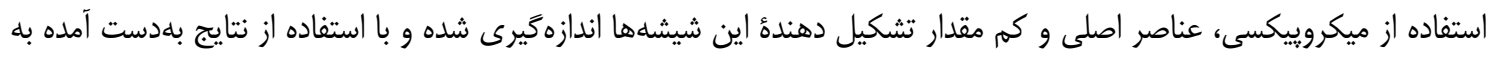

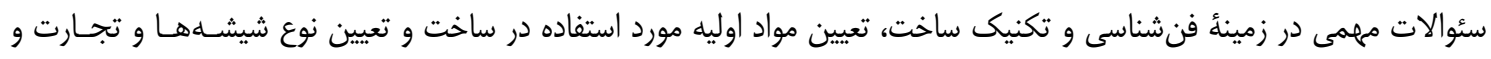

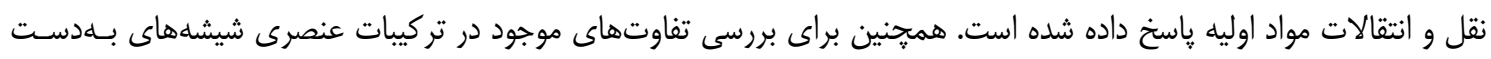

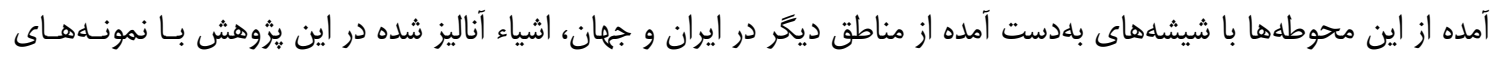

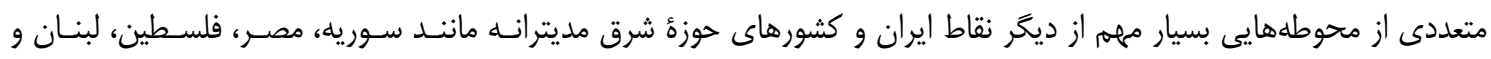

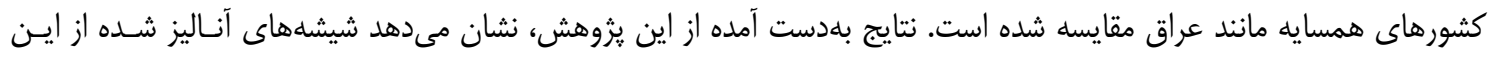

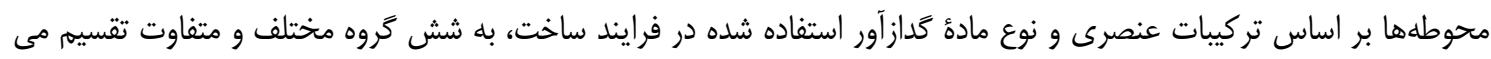

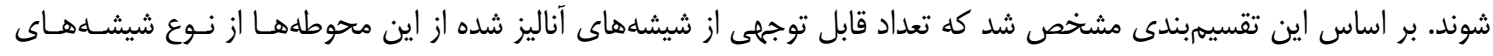

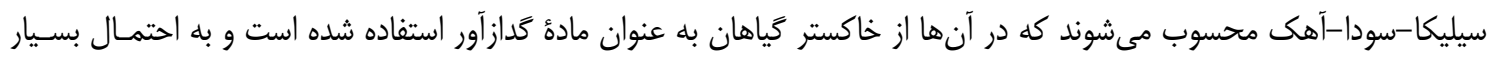

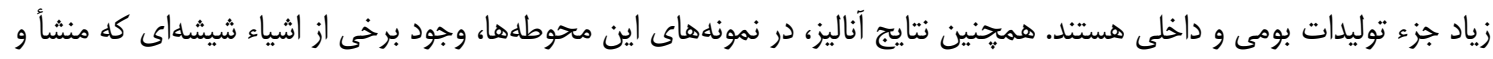

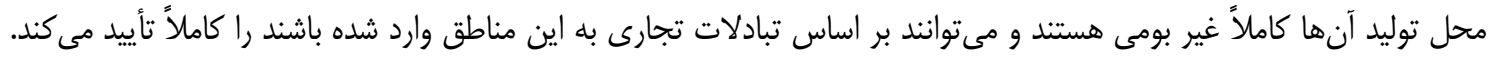

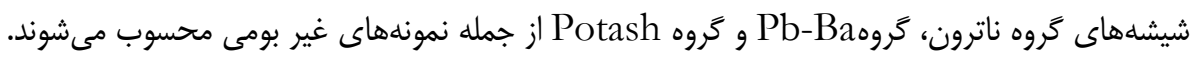
وازًَان كليدى: ميكروييكسى، آناليز عنصرى، قطعات تاريخى كرونى شيشه، ميراث جهانى تخت سليمان، محوطههاى تاريخى اردبيل

" نويسنده مسئول مكاتبات: تهران، انتهاى خيابان كاركَ شمالى، سازمان انرزى اتمى ايران، يُوهشكاه علوم و فنون هستهاى. سيست الكترونيكى: daghaaligol@aeoi.org.ir

C) حق نشر متعلق به نويسنده(كان) است و نويسنده تحت مجوز Creative Commons Attribution License به مجله اجازه مىدهد مقاله خاب شده را با ديخران به اشتراك بحذارد منوط بر اينكه حقوق مؤلف اثر حفظ و وبه به انتشار اوليه مقاله در اين مجله اشاره شود. 
مختلف از جمله شيشههاى تزيئنى مانند النكو، ديواره و بدنهُ ظروف و اشياء شيشهاى با شكل نامشخص هستند

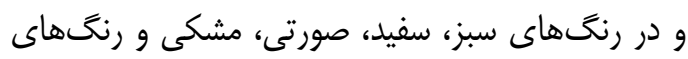
ديخر ساخته شدهاند، با روش ميكروييكسى و با استفاده وندي از شتابدهنده واندوكراف يزوهشكده فيزيك و شتابكرها در يثوهشگاه علوم و فنون هسـتهاى در ايـران، انجـام

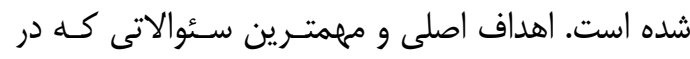

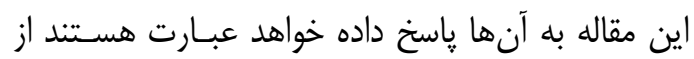
بررسى و اندازهخيرى تركيبات اصلى شيشـهــا، تعيـين

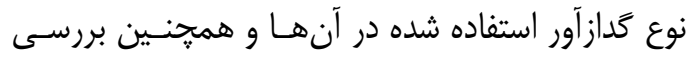

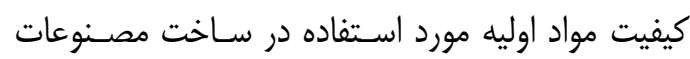

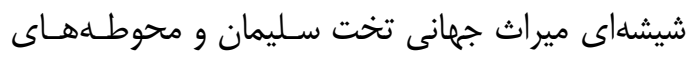

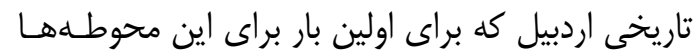

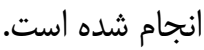

\section{r. بيشينةُ تحقيقاتى آناليز عنصـرى شيشـــ- هاى اير انى} فعاليتها و حفارىهاى باستانشناسـى انجـام شـــه در

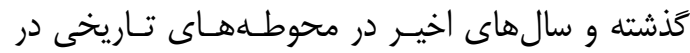

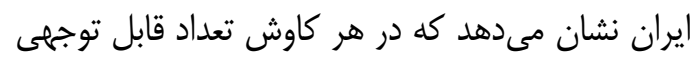
اشياء و مصنوعات شيشهاى بهددست آمده كه بيشتر آن آنها در موزههاى مختلف در كشور نكمهارى مىشوند. اما بررسىها نشان مىدهد كه بر روى اشياء شيشهاى بـهـ-

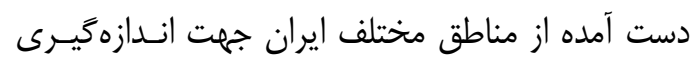

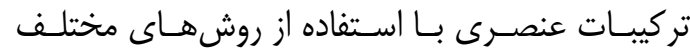

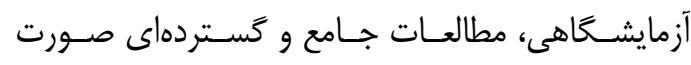

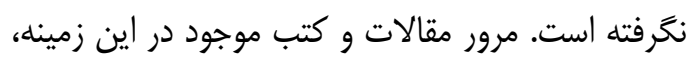
كوياى اين مطلب اسـت كـه در بـين انـدى مطالعـات انجام شده بر روى شيشههاى ايرانى كه توسط محققان

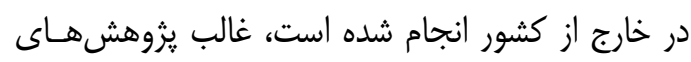
انجام شده بر روى شيشههاى بهدست آمــده از نيشـابور

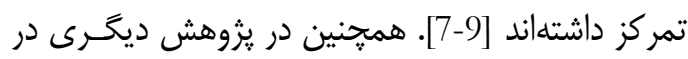

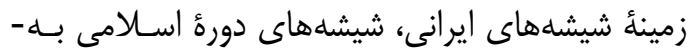
دست آمده از بندر سيراف در جنوب ايران، مورد مطالعه

قرار كرفتهاند [10]. در داخل كشور نيز آنـاليز عنصـرى، بررسى و تحليـل تركيبات تشكيل دهندة شيشههـاى تـاريخى ايـران در

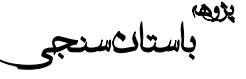

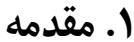

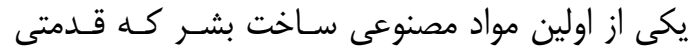

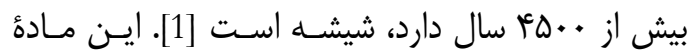

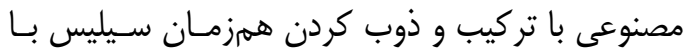

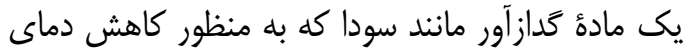

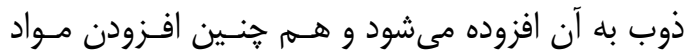
استحكام بخـش و شـبكهسـاز (network stabilizer) مانند كربنات كلسيم ساخته شده است. علاوه بــر ايـن،

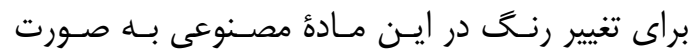

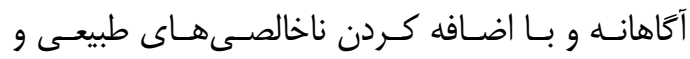

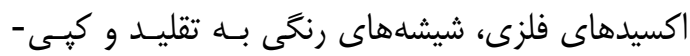

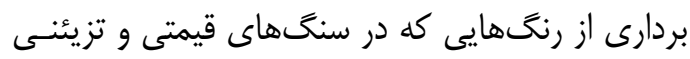

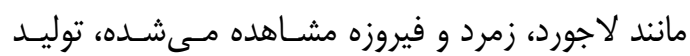

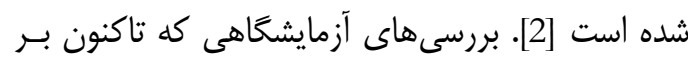

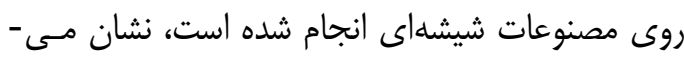
دهد تركيبات شيميايى و عنصرى شيشههاى باستانى از

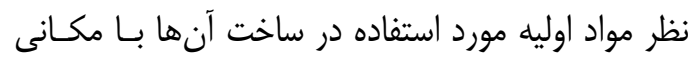

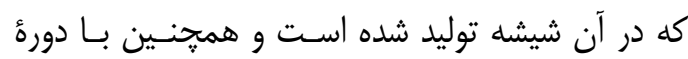

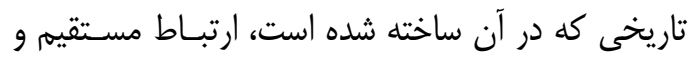
معنــى دارى دارد [2,3]. از طـــرف ديخـــر، مطالعــات آزمايشگاهى نشان داده است كه تركيب عنصرى شيشه به طور مستقيم منعكس كننده مواد اولئ مورد استفاده

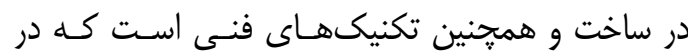

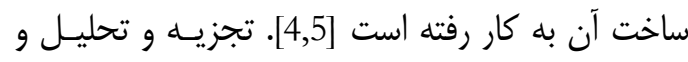

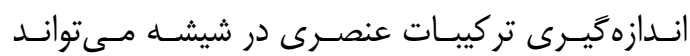
شواهدى در مورد نوع مواد اولئُ مورد اسـتفاده و منشـأ عناصر مختلف در تركيبات نهايى شيشه و بررسى علـل مورد

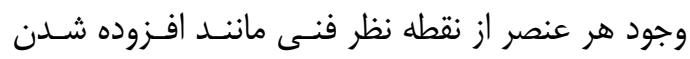

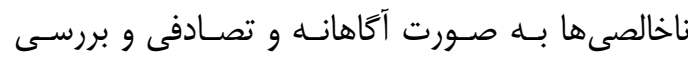

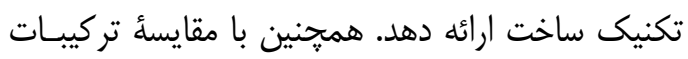

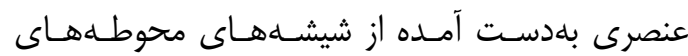

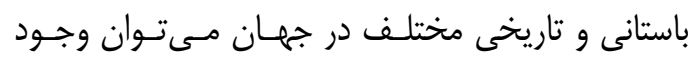

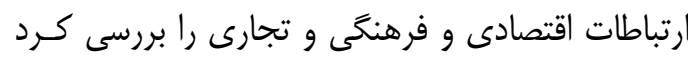

در اين كار يزوهشى، آناليز عنصرى عس نمونه از قطعات

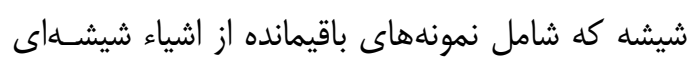


با مواد استفاده شده در نمونههاى ساسانى بهدست آمده

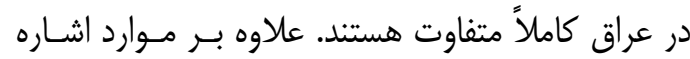

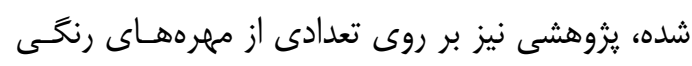

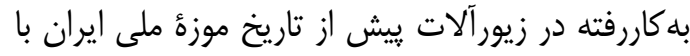
قدمت هزارة سوم تا اول ق.م انجام شده است و نتسايج

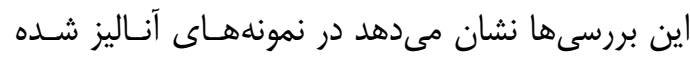

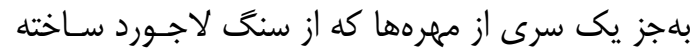
شدهاند، ساير مهرهها از جنس شيشه سيليكا - سـودا-

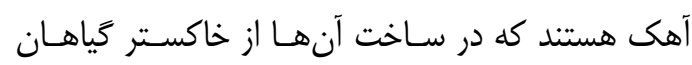

بلعنوان ماده كَازآ آور استفاده شده است [15].

\section{س. موقعيت جغر افيايى و ييشينه كـاوشهــاى

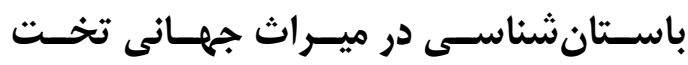
سليمان و محوطههاى اردبيل

مجموعه ميراث جهانى تخـت سـليمان كـه در تيرمـاه

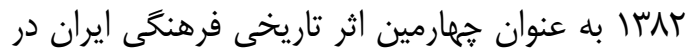

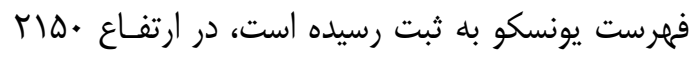

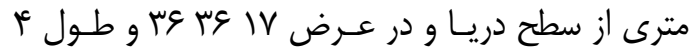

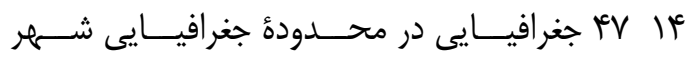

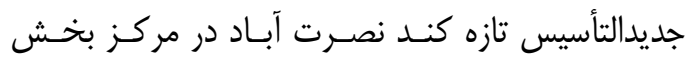
تخت سليمان، و هأ كيلومترى شمال شرقى شهر تكاب

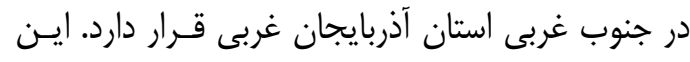

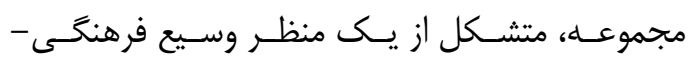

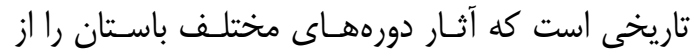
يارينه سنگى ميانى و تاريخى تا دوره اسلامى در بردارد

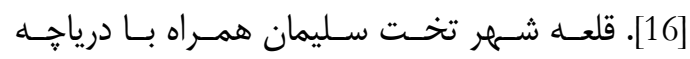
سحرانخيز، زندان سـليمان مخــوف، كـوه طويلـه، كـوه

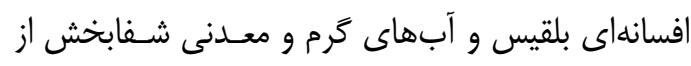

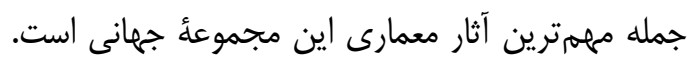
همجنين كشـف و شناسـيى ابزارهـاى سـنَّى و آثـار

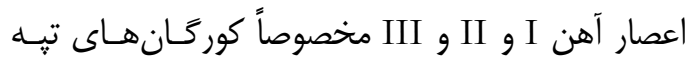

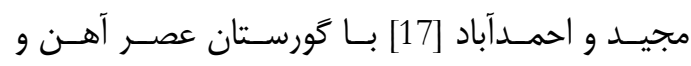
استقرارهاى سدههاى هشـتم و هفـتم قبـل از مـيلاد و

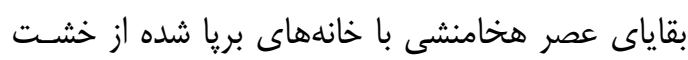

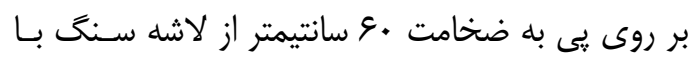

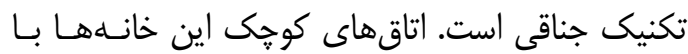

$\mu \mu$

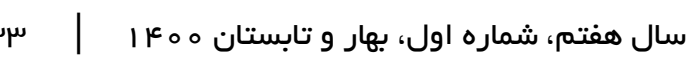

سال وqسا، با هدف مشخص شدن קالشهاى موجـود

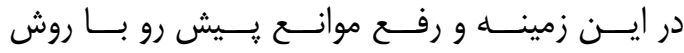

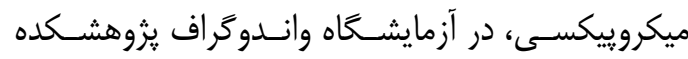

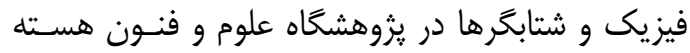

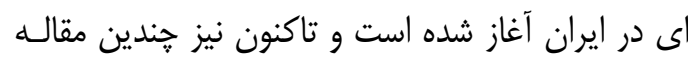

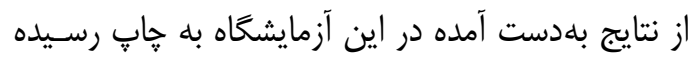

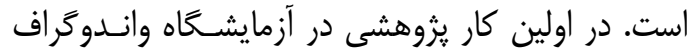

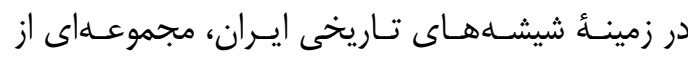

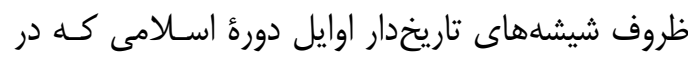

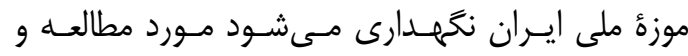
بررسى قرار كرفتند [11]. نتايج اين آزمايشات نشان داد

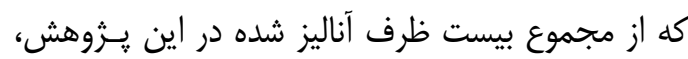
به جز يك نمونه كه كداز آور استفاده شده در آن ناترون

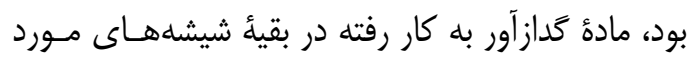

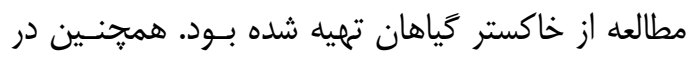

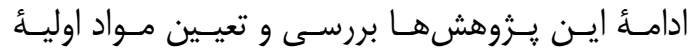

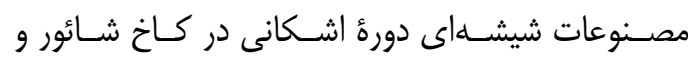

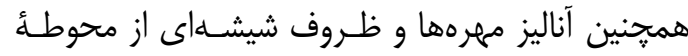
صالح داود در شوش انجام شد كه نتايج بهدست آمده از

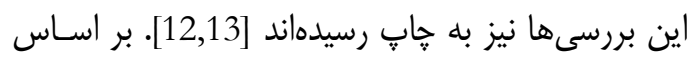

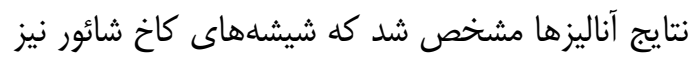

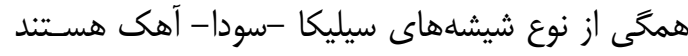

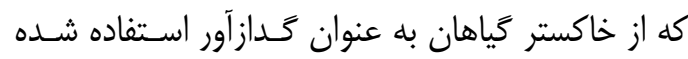

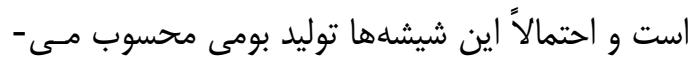

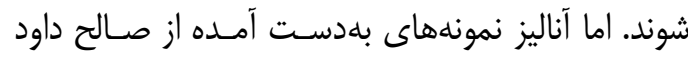
نشان داد كه در مهرههاى شيشهاى صالح داود از مـاده معدنى ناترون و در ظروف بلهدست آمده از صالح داود از

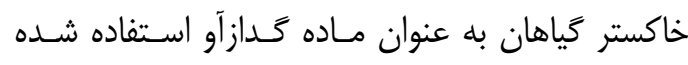

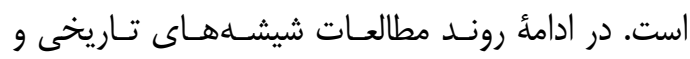

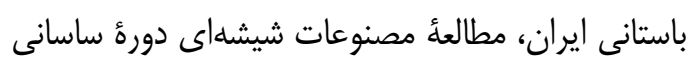

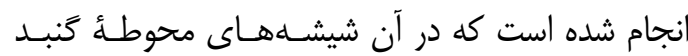

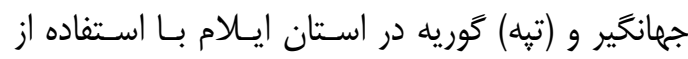

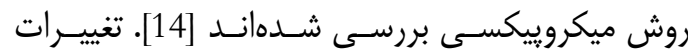

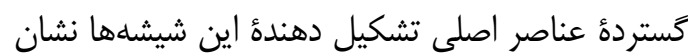

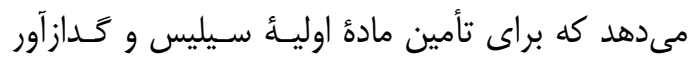

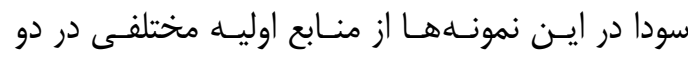
محوطة مورد بررسى استفاده شده است و اين مواد اوليه 
[26,28]. اين شهر در اوايـل دورة اسـلامى بــه عنــان

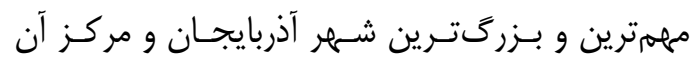

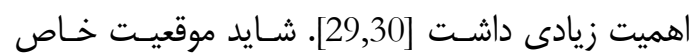

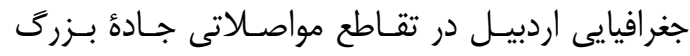

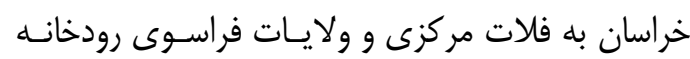

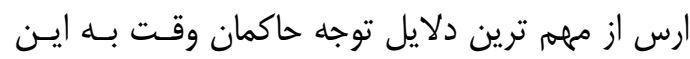
شهر و ناحيه در دورههاى قبل از اسلام و عصر اسلامى تلى المان

با توجه به موارد برشمرده در بالا، نمونههاى آناليز شده از محوطههاى باستانى واقع در كنارههاى رودخانئ قـره

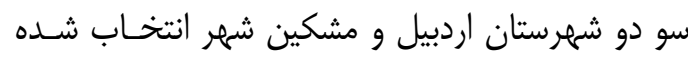

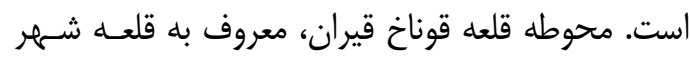

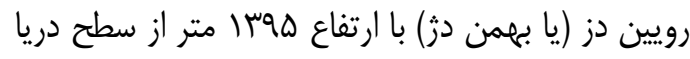

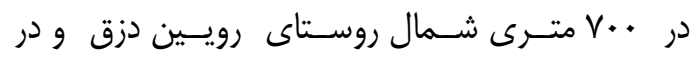

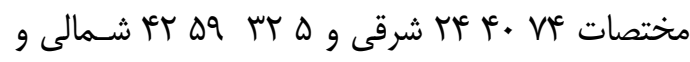

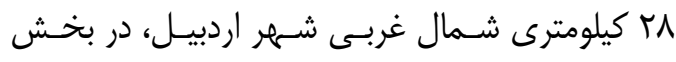

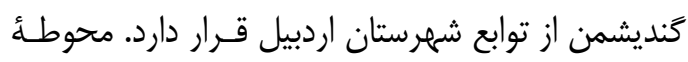

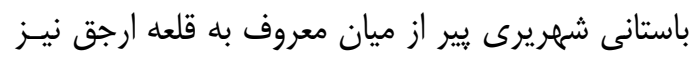

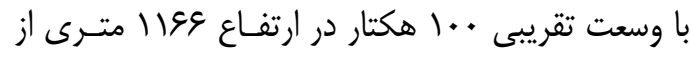

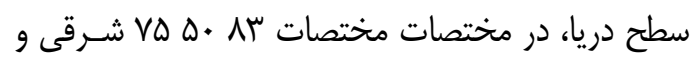

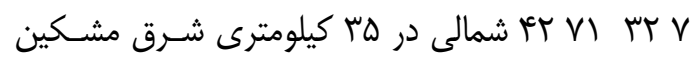

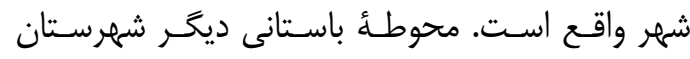

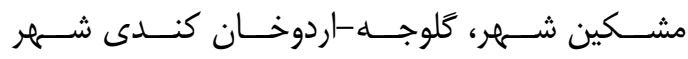

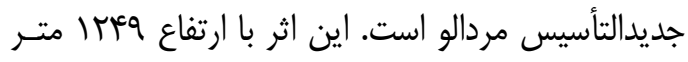

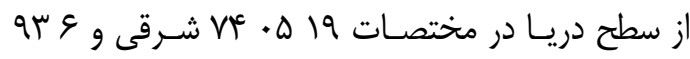
عم זr شمالى در دره كلوجه در شمال دشت حاصــاتخيز

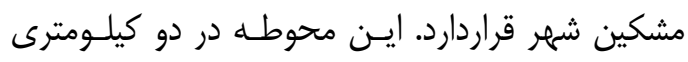

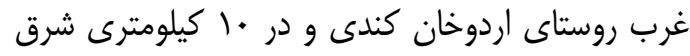

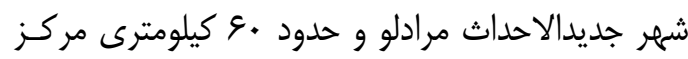
شهرستان واقع است.

\section{ع. مواد و روشها}

I-ع. معرفى شيشـهـهـاى مجموعسه ميـراث

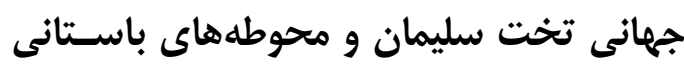
اردبيل
زواياى مايل، طرح ساده داشتند و در كَورهاى انفـرادى با تدفين جنينى در داخل اتاقهـا، قطعـات سـفالهـاى

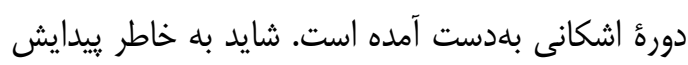
همين آثار و ديخر شواهد تاريخى است كه آرتـور ايهـام يوضٍ و بعضى از محققان، تخت سـليمان را منطبـق بــــا

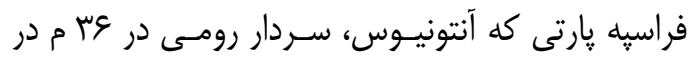
لشكر كشى خـود محاصـره كـرد ولى تسـخير نكـرد، دانستهاند[18]. امـا اوج عظمـت و شـكوه تخـت ســليمان دورههــاى

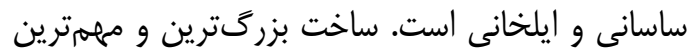

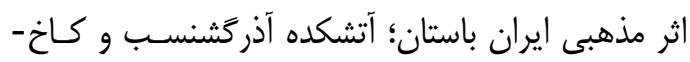

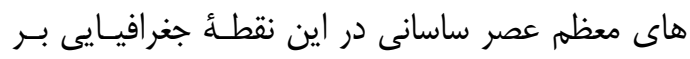

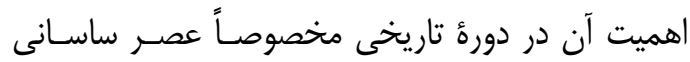

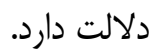

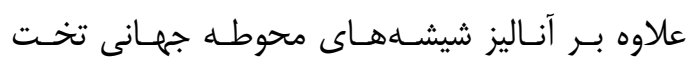

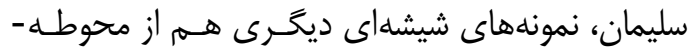

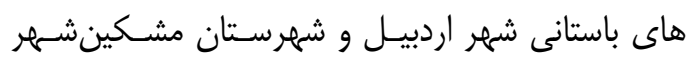

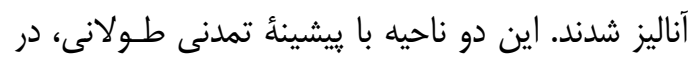

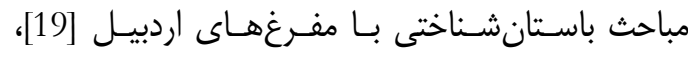

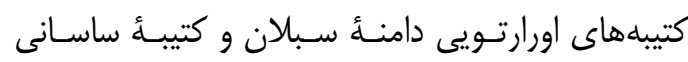

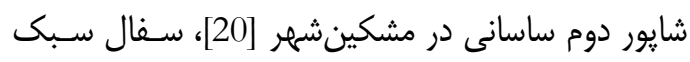

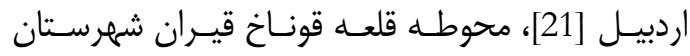

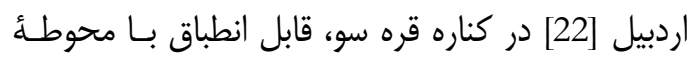

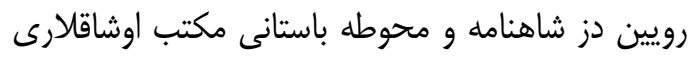

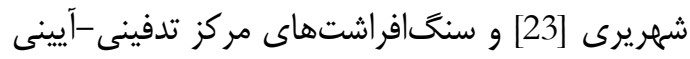
آن متعلق به عصر آهن و قــدمت اسـتقرار آن بــه دوره

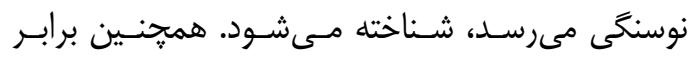

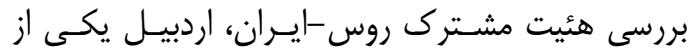
اولين نقاطى است كه دورههاى يارينه سنكى، فر إيارينـهـ

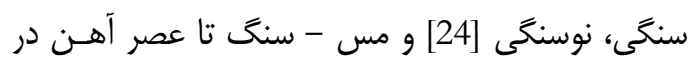

$$
\text { آن شناسايى و معرفى شده است [25] }
$$

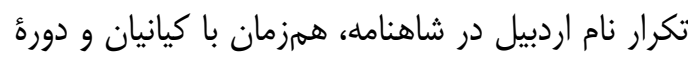
يادشاهى كيكاووس بر اهميت شـهر اردبيـل و ييشـينه

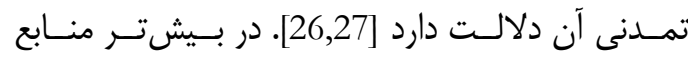
سدهاى اوليه اسلامى، بناى شهر اردبيل به شهريار إنسان

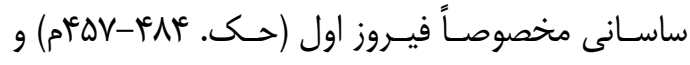

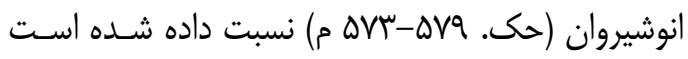

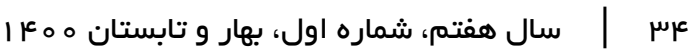


ميراث جهانى تخت سليمان و V نمونه نيـز مربـوط بــاه

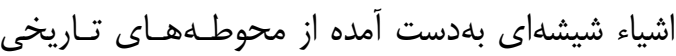

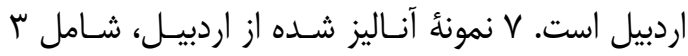
نمونه از قلعه قوناخقيران در روستاى رويين دز، إنمونه

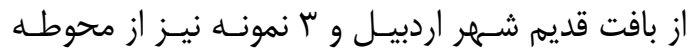
باستانى مشكين شهر در اردبيل است. موقعيت جغرافيايى محوطههاى تاريخى تخت سـليمان

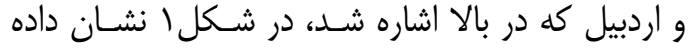
شده است. همجنين مشخصات اشياء آناليز شده شـامل كد نمونهها، فرم ظاهرى، محل اكتشاف نمونههـا، دوره

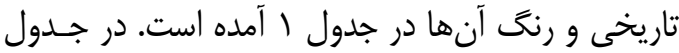

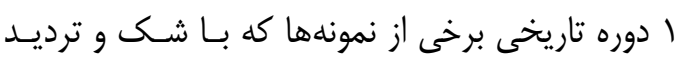
همراه بوده است با علامت (؟) نشان داده شــده اسـت. همجنين تصاوير إيتيكى تمام نمونههاى آناليز شده نيـز در شكل r ارائه شده است.
در اين كار يزوهشى، آنـاليز عنصــى عس نمونـهـ از هـ شىء شيشهاى به دست آمده از مجموعه ميراث جهانى

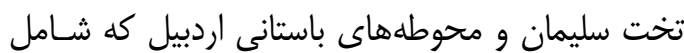

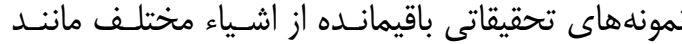
النكو، بدنه ظروف و اشيائى با اشكال نامشخص هستند،

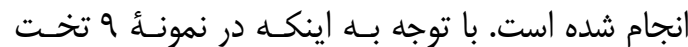
سليمان دو طيف رنكى سبز روشن و سبز تيره در لبها و بدنهُ ظرف ديده مى شدند، بنابراين از نمونه شماره ج، دو نمونه براى آناليز انتخاب شده است. نمونههاى انتخـاب

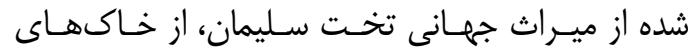

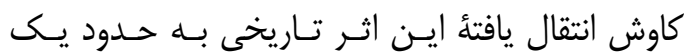

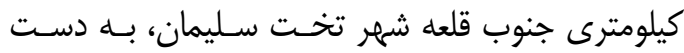

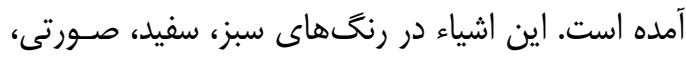
مشكى و آبى توليد شدهاند. از مجموع عَ نمونـهـ آنـاليز

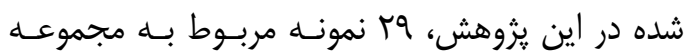

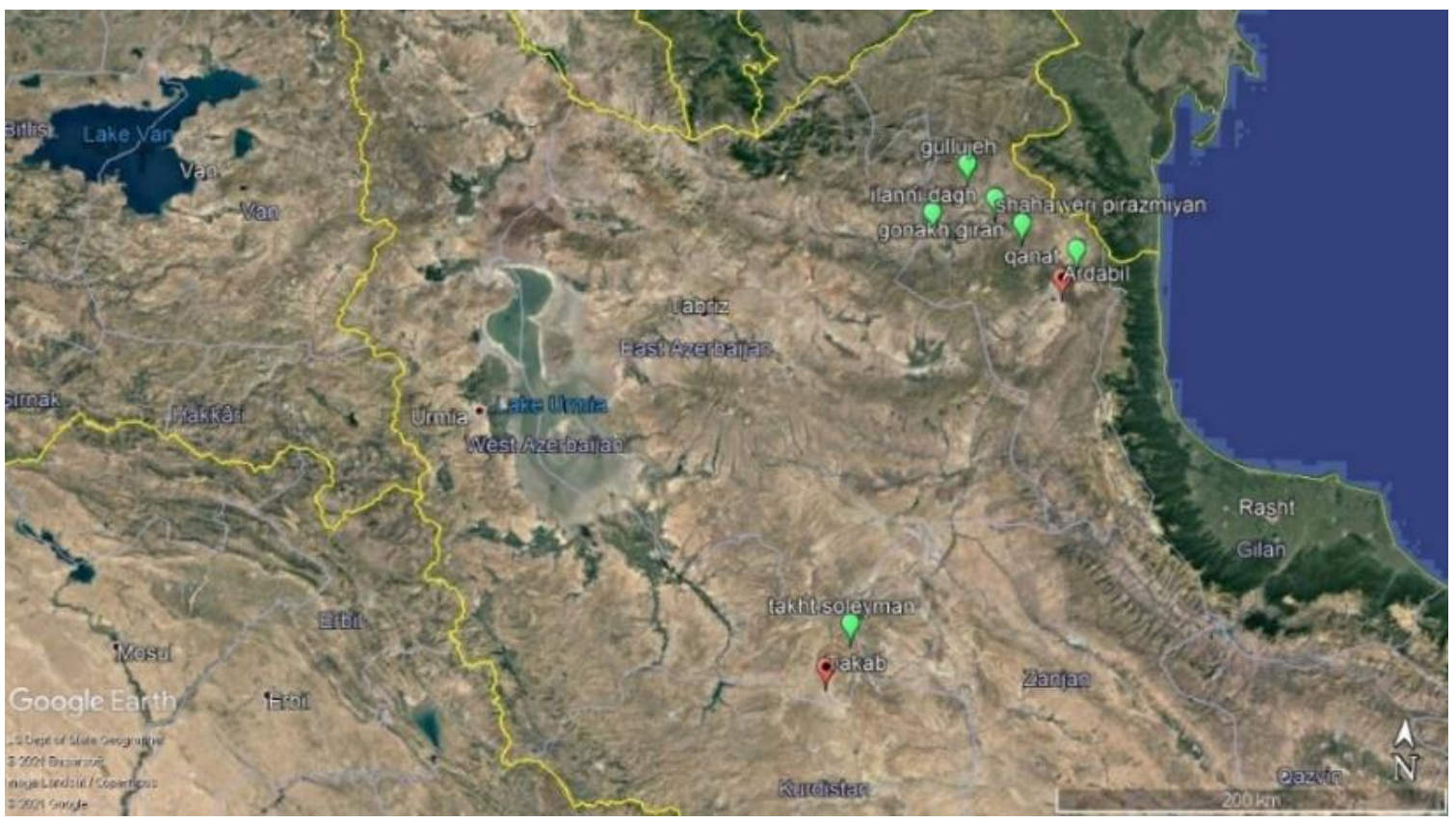

شكل ا: موقعيت جغرافيايى ميراث جهانى تخت سليمان و محوطههاى باستانى اردبيل با رنح سبز مشخص است (Google earth)

Fig. 1: A map of Iran showing the geographical location of Takht-e Suleyman World Heritage and Ardabil archaeological sites 
جدول (: مشخصات ظاهرى و باستان شناسى مصنوعات شيشهاى آناليز شده از تخت سليمان و اردبيل

Table 1: Characteristics of analyzed glass artifacts from Takht-e Suleiman and Ardabil

\begin{tabular}{|c|c|c|c|c|}
\hline دوره تاريخى & رن & محل اكتشاف نمونه & فرم شى & كد نمونه \\
\hline Historical period & Color & Excavation site & Form & Sample code \\
\hline Islamic & Dark green & Takht-e Suleiman World Heritage & Unknown & Takht-Su1 \\
\hline Islamic & Dark green & Takht-e Suleiman World Heritage & Unknown & Takht-Su2 \\
\hline Islamic & Light green & Takht-e Suleiman World Heritage & Vessel edge & Takht-Su3 \\
\hline Sassanid & Black & Takht-e Suleiman World Heritage & Unknown & Takht-Su4 \\
\hline Islamic & Light green & Takht-e Suleiman World Heritage & Unknown & Takht-Su5 \\
\hline Islamic & Violet & Takht-e Suleiman World Heritage & Bracelet & Takht-Su6 \\
\hline Sassanid & Black & Takht-e Suleiman World Heritage & Unknown & Takht-Su7 \\
\hline Sassanid & Black & Takht-e Suleiman World Heritage & Vessel edge & Takht-Su8 \\
\hline Sassanid? & Light green & Takht-e Suleiman World Heritage & Unknown & Takht-Su9 \\
\hline Sassanid? & Dark green & Takht-e Suleiman World Heritage & Vessel base & Takht-Su10 \\
\hline Islamic & Violet & Takht-e Suleiman World Heritage & Bracelet & Takht-Su11 \\
\hline Sassanid & Black & Takht-e Suleiman World Heritage & Unknown & Takht-Su12 \\
\hline Sassanid & Black & Takht-e Suleiman World Heritage & Unknown & Takht-Su13 \\
\hline Islamic & Light green & Takht-e Suleiman World Heritage & Unknown & Takht-Su14 \\
\hline Islamic & Light green & Takht-e Suleiman World Heritage & Vessel edge & Takht-Su15 \\
\hline Sassanid & Dark green & Takht-e Suleiman World Heritage & Vessel edge & Takht-Su16 \\
\hline Sassanid & Black & Takht-e Suleiman World Heritage & Unknown & Takht-Su17 \\
\hline Islamic & Light green & Takht-e Suleiman World Heritage & Unknown & Takht-Su18 \\
\hline Islamic & Dark green & Takht-e Suleiman World Heritage & Vessel edge & Takht-Su19 \\
\hline Sassanid & Emerald green & Takht-e Suleiman World Heritage & Unknown & Takht-Su20 \\
\hline Islamic & Colorless & Takht-e Suleiman World Heritage & Unknown & Takht-Su21 \\
\hline Islamic & Colorless & Takht-e Suleiman World Heritage & Unknown & Takht-Su22 \\
\hline Islamic & Light green & Takht-e Suleiman World Heritage & Unknown & Takht-Su23 \\
\hline Islamic & Light green & Takht-e Suleiman World Heritage & Unknown & Takht-Su24 \\
\hline Islamic & Turquoise blue & Takht-e Suleiman World Heritage & Unknown & Takht-Su25 \\
\hline Islamic & Turquoise blue & Takht-e Suleiman World Heritage & Bracelet & Takht-Su26 \\
\hline Sassanid & Dark green & Takht-e Suleiman World Heritage & Unknown & Takht-Su27 \\
\hline Sassanid & Colorless & Takht-e Suleiman World Heritage & Unknown & Takht-Su28 \\
\hline Sassanid? & Turquoise blue & Gonakh giran-Ardabil & Unknown & Ardabil 1 \\
\hline Sassanid & Light green & Shaharyeri-Meshkinshar & Unknown & Ardabil 2 \\
\hline Sassanid & Dark green & Gonakh giran-Ardabil & Vessel edge & Ardabil 3 \\
\hline Sassanid & Brown & Gonakh giran-Ardabil & Vessel edge & Ardabil 4 \\
\hline Islamic & Colorless & Ardabil & Unknown & Ardabil 5 \\
\hline Islamic & Purple & Gullujeh- Meshkinshar & Vessel edge & Ardabil 6 \\
\hline Islamic? & Dark green & Ilanni dagh- Meshkinshar & Bracelet & Ardabil 7 \\
\hline
\end{tabular}




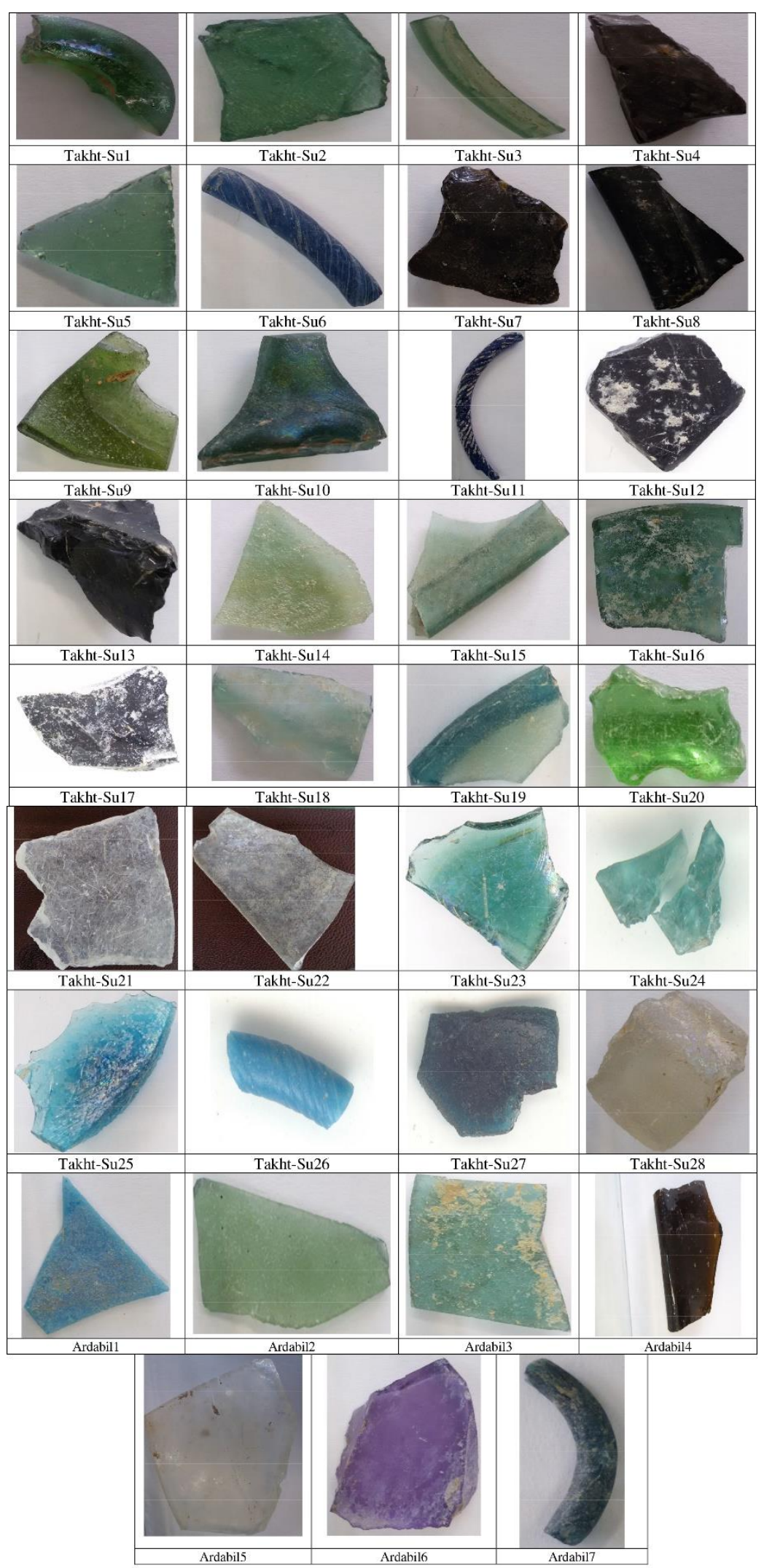

شكل ז: تصاوير إيتيكى تمام نمونهای آناليز شده از محوطه تاريخى تخت سليمان و محوطههاى باستانى اردبيل

Fig. 2: Optical photo of all analyzed samples from Takht-e Suleiman historical site and Ardabil ancient sites. 
عناصر موجود در نمونه مورد بررسى را مشخص مى كند

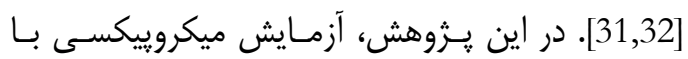

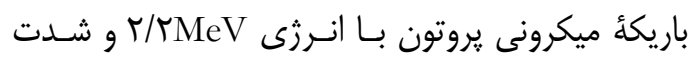

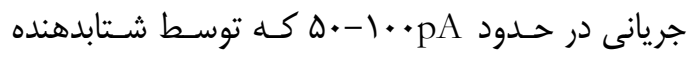

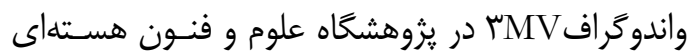

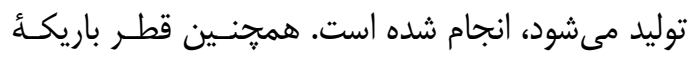

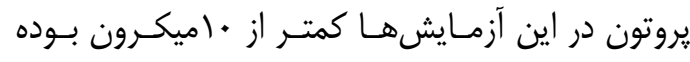

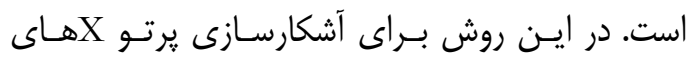

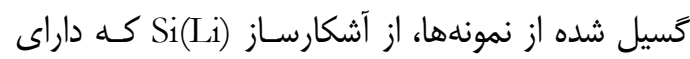

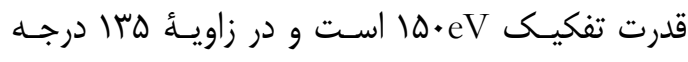
نسبت به يرتوهاى يروتون فرودى قرار كرفته، اسـتفاده

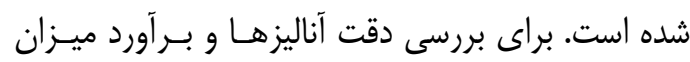

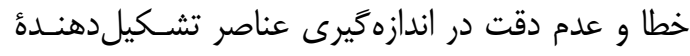

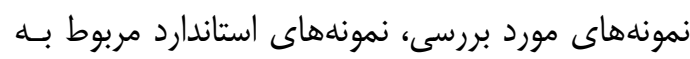

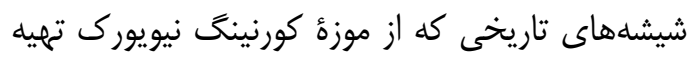
شده، همزمان و تحت شرايط يكسان با نمونهها، مـورد

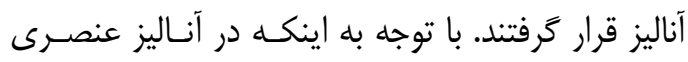
اشياء شيشهاى مورد مطالعه از تخت سـليمان و اردبيـل

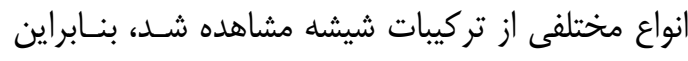

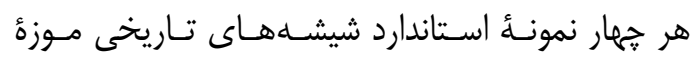

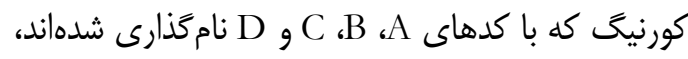

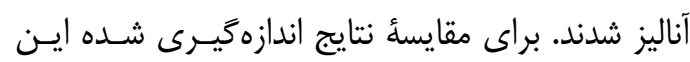

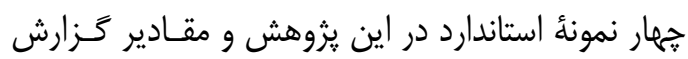

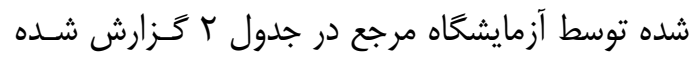

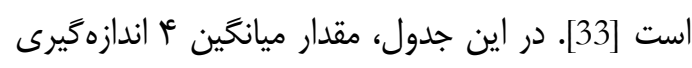

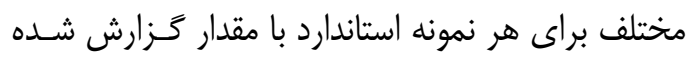

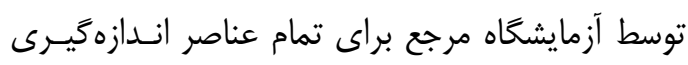

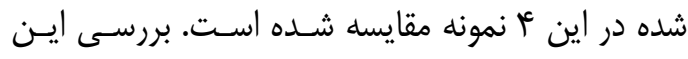
جدول نشان مى دهد كه روش ميكروييكسى قادر اسـت إنس با دقت بسيار خوبى تركيبات عناصر تشكيل دهندة انواع مختلف شيشههاى تاريخى را اندازهيرى كند.

\section{ץ-ع. آناليز عنصرى با روش ميكروييكسى}

براى اندازهكيرى تركيبات عنصرى عس نمونسه از اشـياء

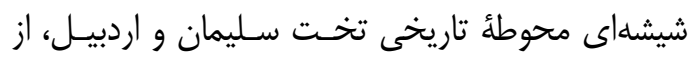
روش ميكروييكسى در آزمايشگاه واندوكراف يثروهشگاه

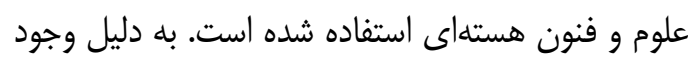

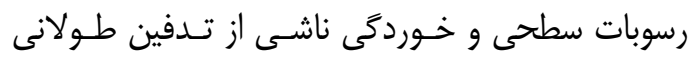

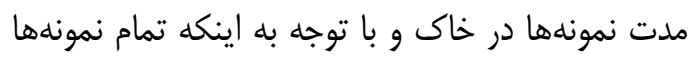

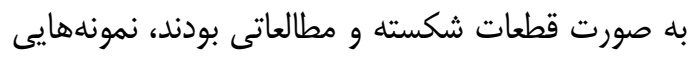

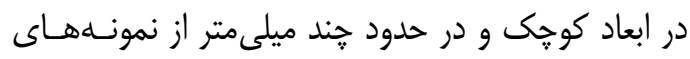
مورد مطالعه جدا و از سطح مقطع آنهـا آنـاليز شـدند.

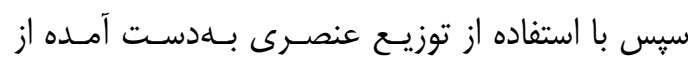

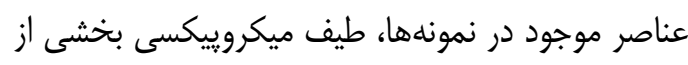

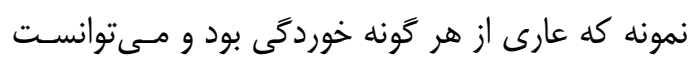

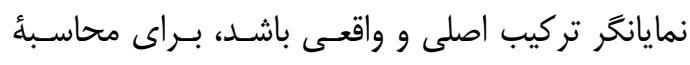

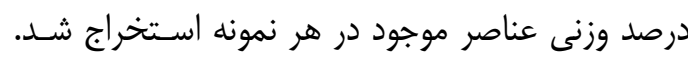

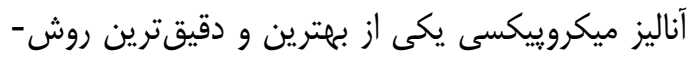

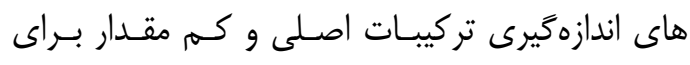

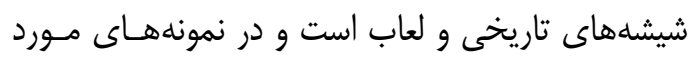

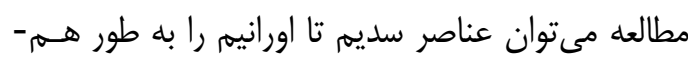

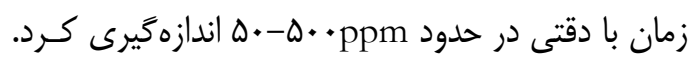

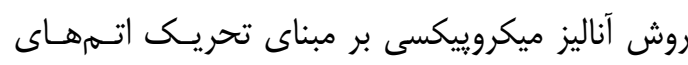

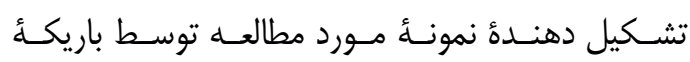
يروتونهاى يرانرزى كه توسط شتاب دهنده واندوكراف

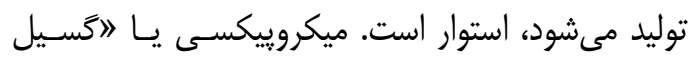

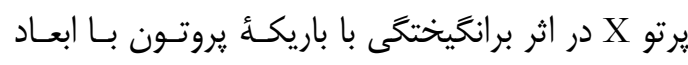

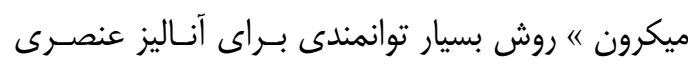

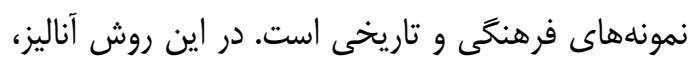

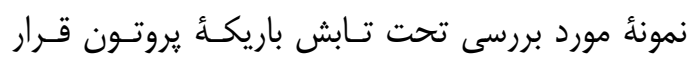

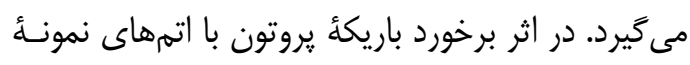

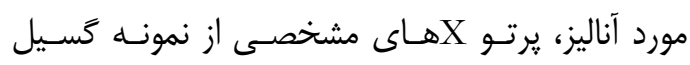

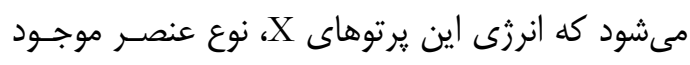

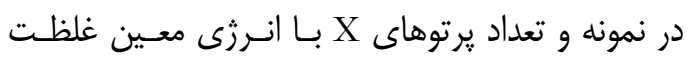




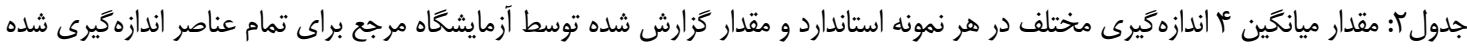

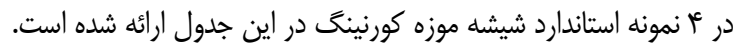

Table 2: The mean value of 4 different measurements in each glass standard and the quoted value for all elements measured in the 4 Corning glass standard.

\begin{tabular}{|c|c|c|c|c|c|c|c|c|}
\hline \multirow[b]{2}{*}{$\begin{array}{l}\text { Standard } \\
\text { Samples }\end{array}$} & \multicolumn{2}{|c|}{$\mathbf{A}$} & \multicolumn{2}{|c|}{ B } & \multicolumn{2}{|c|}{ C } & \multicolumn{2}{|c|}{ D } \\
\hline & $\begin{array}{l}\text { Measure } \\
\text { d (wt.\%) }\end{array}$ & $\begin{array}{c}\text { Quoted } \\
\text { (wt.\%) }\end{array}$ & $\begin{array}{l}\text { Measured } \\
(\text { wt.\%) }\end{array}$ & $\begin{array}{l}\text { Quoted } \\
\text { (wt.\%) }\end{array}$ & $\begin{array}{c}\text { Measured } \\
\text { (wt.\%) }\end{array}$ & $\begin{array}{l}\text { Quoted } \\
\text { (wt.\%) }\end{array}$ & $\begin{array}{c}\text { Measured } \\
\text { (wt.\%) }\end{array}$ & $\begin{array}{c}\text { Quoted } \\
\text { (wt.\%) }\end{array}$ \\
\hline $\mathrm{Na}_{2} \mathrm{O}$ & 14.59 & 14.30 & 17.33 & 17.00 & 0.94 & 1.07 & 1.27 & 1.20 \\
\hline MgO & 2.69 & 2.66 & 1.04 & 1.03 & 2.37 & 2.67 & 4.05 & 3.94 \\
\hline $\mathrm{Al}_{2} \mathbf{O}_{3}$ & 1.12 & 1.00 & 4.24 & 4.26 & 1.30 & 0.87 & 5.84 & 5.30 \\
\hline $\mathrm{SiO}_{2}$ & 66.66 & 66.56 & 61.95 & 61.55 & 34.87 & 34.78 & 56.42 & 55.24 \\
\hline $\mathbf{P}_{2} \mathbf{O}_{5}$ & 0.16 & 0.13 & 1.10 & 0.82 & 0.04 & 0.14 & 4.23 & 3.93 \\
\hline $\mathrm{SO}_{3}$ & 0.14 & 0.10 & 0.60 & 0.50 & 0.03 & 0.10 & 0.16 & 0.30 \\
\hline $\mathrm{Cl}$ & 0.14 & 0.10 & 0.24 & 0.20 & 0.15 & 0.10 & 0.12 & 0.40 \\
\hline $\mathbf{K}_{2} \mathbf{O}$ & 2.70 & 2.87 & 1.01 & 1.00 & 2.60 & 2.84 & 10.7 & 11.3 \\
\hline $\mathrm{CaO}$ & 4.58 & 5.03 & 8.04 & 8.56 & 4.66 & 5.07 & 13.1 & 14.8 \\
\hline $\mathrm{TiO}_{2}$ & 0.77 & 0.79 & 0.11 & 0.09 & 0.66 & 0.79 & 0.35 & 0.38 \\
\hline $\mathrm{MnO}$ & 1.01 & 1.00 & 0.24 & 0.25 & 0.21 & 0.89 & 0.50 & 0.55 \\
\hline $\mathrm{Fe}_{2} \mathrm{O}_{3}$ & 1.10 & 1.09 & 0.34 & 0.34 & 0.30 & 0.34 & 0.47 & 0.52 \\
\hline $\mathrm{CoO}$ & 0.18 & 0.17 & 0.05 & 0.05 & 0.18 & 018 & 0.01 & 0.02 \\
\hline $\mathrm{NiO}$ & 0.02 & 0.02 & 0.09 & 0.10 & 0.02 & 0.02 & 0.05 & 0.05 \\
\hline $\mathrm{Cu}_{2} \mathrm{O}$ & 1.13 & 1.17 & 2.58 & 2.66 & 1.27 & 1.13 & 0.33 & 0.38 \\
\hline $\mathrm{ZnO}$ & 0.06 & 0.04 & 0.21 & 0.16 & 0.05 & 0.05 & 0.10 & 0.10 \\
\hline $\mathrm{SrO}$ & 0.11 & 0.10 & 0.01 & 0.02 & 0.26 & 0.29 & 0.04 & 0.06 \\
\hline $\mathrm{SnO}_{2}$ & 0.60 & 0.19 & 0.00 & 0.02 & 0.09 & 0.19 & 0.00 & 0.10 \\
\hline $\mathrm{Sb}_{2} \mathrm{O}_{5}$ & 1.55 & 1.75 & 0.24 & 0.46 & 0.01 & 0.03 & 0.95 & 0.97 \\
\hline $\mathrm{BaO}$ & 0.45 & 0.56 & 0.02 & 0.05 & 11.51 & 11.40 & 0.27 & 0.51 \\
\hline $\mathrm{PbO}$ & 0.09 & 0.12 & 0.52 & 0.61 & 37.76 & 36.70 & 0.44 & 0.48 \\
\hline
\end{tabular}




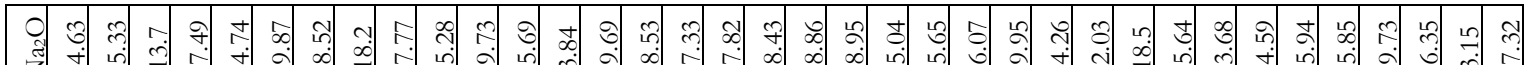

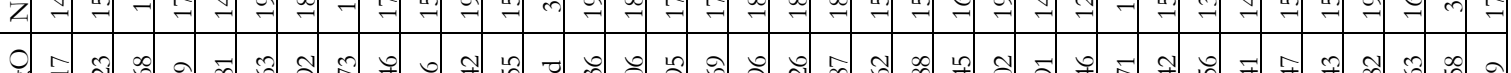

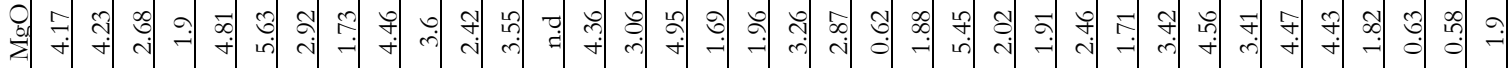

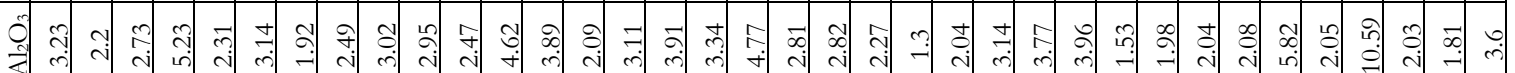

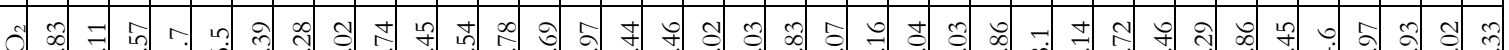

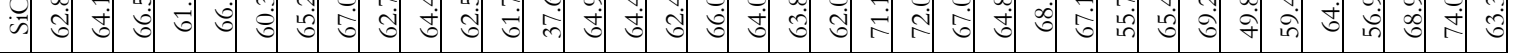

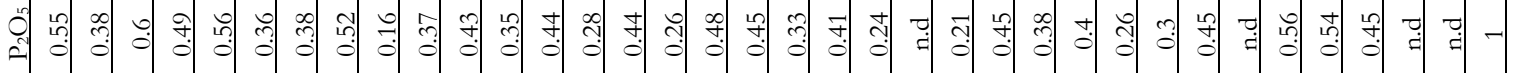

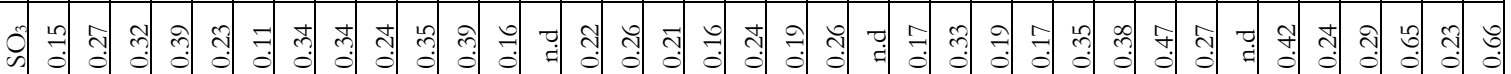

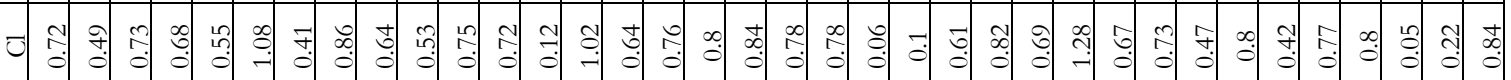

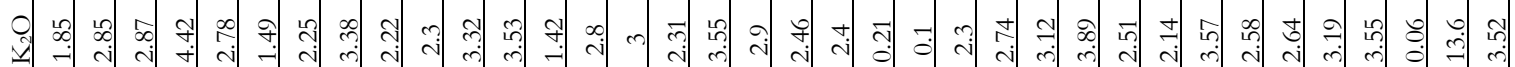

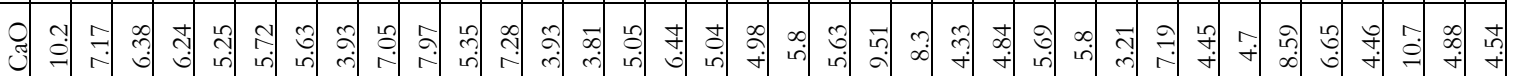

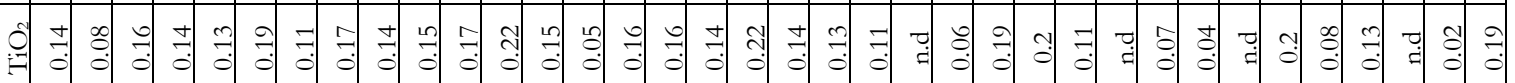

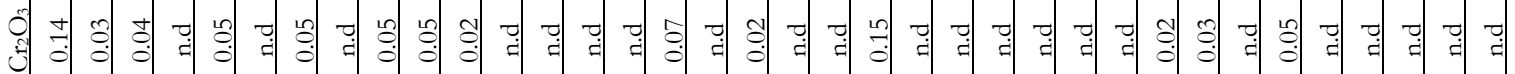
自

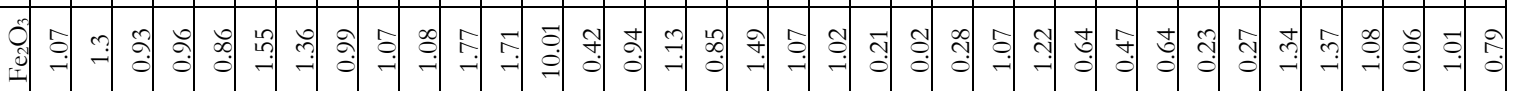

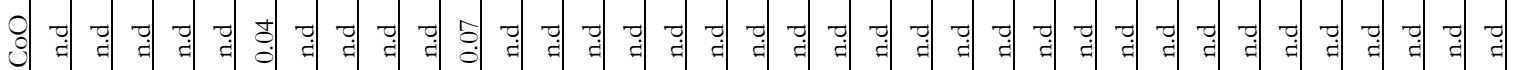
b)

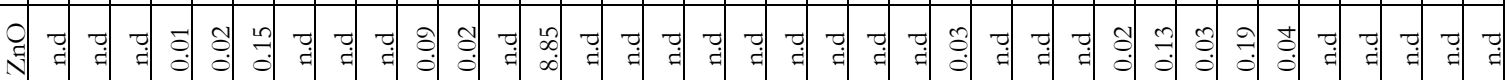

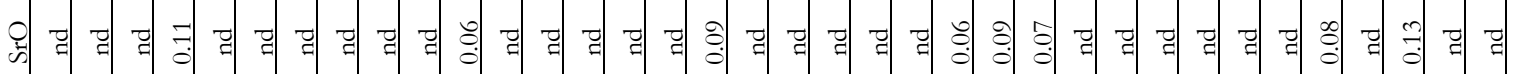
全

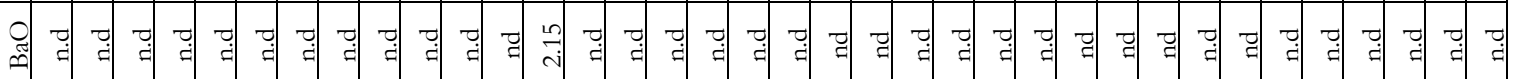

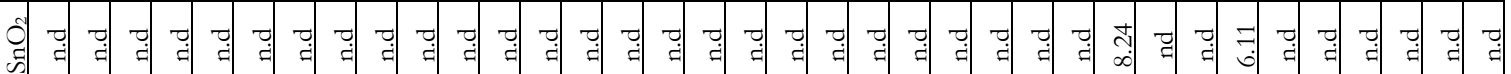

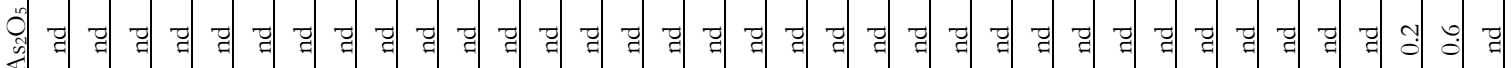

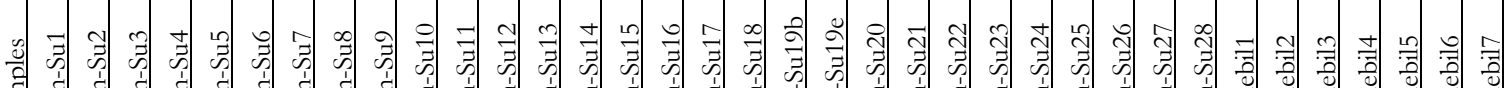

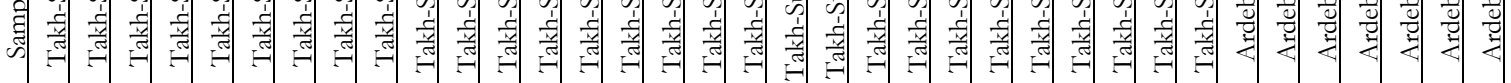


و اكسيد سديم به طور همزمان استفاده شده است، ديده مىشود [37]. علاوه براين نمونههايى از شيشههاى نوع

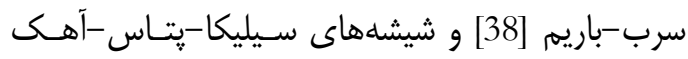

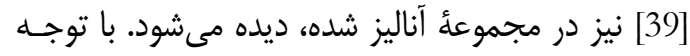

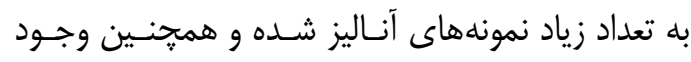
كروههاى مختلفى از انواع شيشهها در اين محوطـهـهـا،

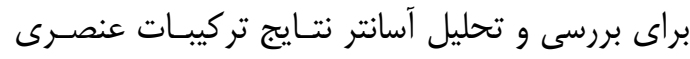

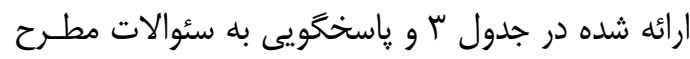

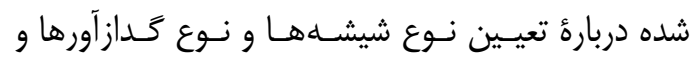

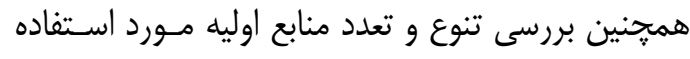

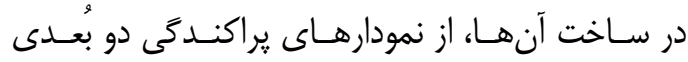

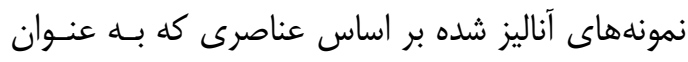
شاخص و تعيين كنندة هر مادة اوليسه هسـتند، اسـتفاده

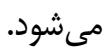

ا -0. طبقدبندى شيشههاى ميراث جهانى تخت سليمان و محوطههایى باستانى اردبيل بر اساس ماده كَداز آور

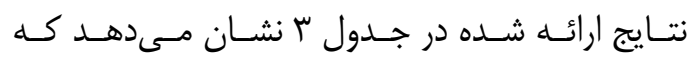
كَدازآورهاى متفاوت و كَوناگونى در ساخت شيشههـاى

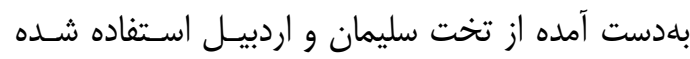
است. براى بررسى و طبقهبندى اين شيشهها بر اسـاس إديس

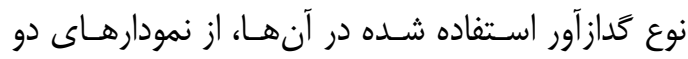

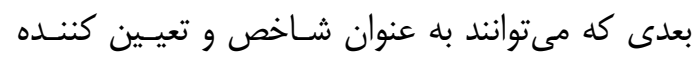

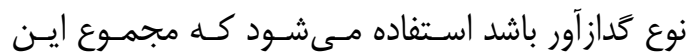
نمودارها در شكل ب نشان داده شده است.

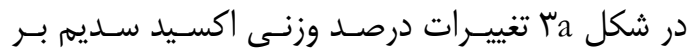
حسب اكسيد يتاسيه براى تمام شيشههاى آناليز شده از

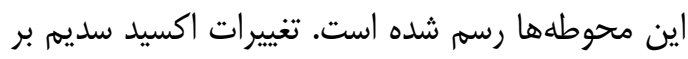

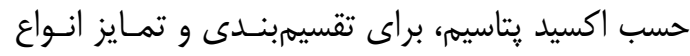

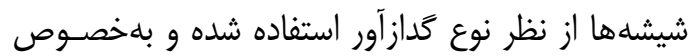

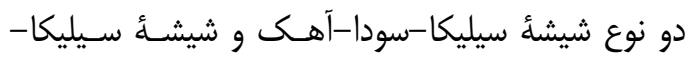
يتاس -آهك بسيار مفيد و قابل استفاده است. همان طور كه در شكل ra مشاهده مى شود، شيشههاى آناليز شده از اين محوطهها در شش كروه قابل طبقابندى هستند.

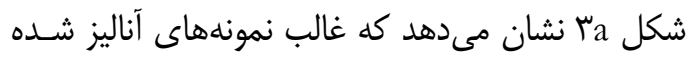

cl

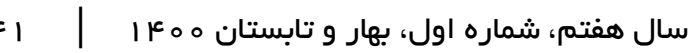

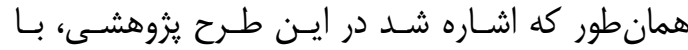

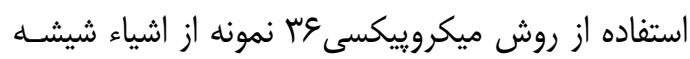

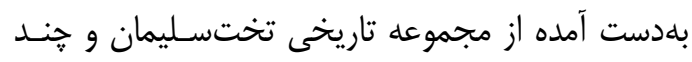

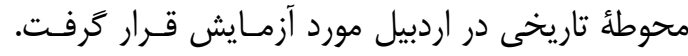

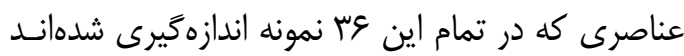

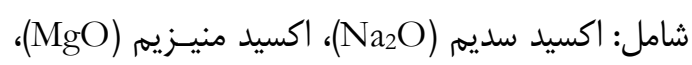
اكسـيد آلومنيـوم ( ${ }^{\prime}$ اكسيد فسفر (

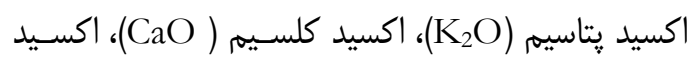

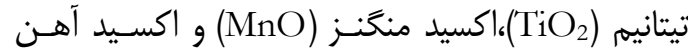
( $\left(\mathrm{Fe}_{2} \mathrm{O}_{3}\right)$

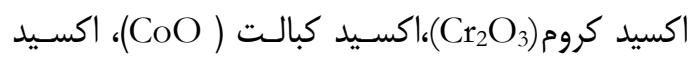

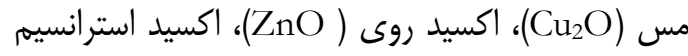
و اكسيد سرب ( PrO ) علاوه بر اين در يكى از نمونهها اكسيد باريم (

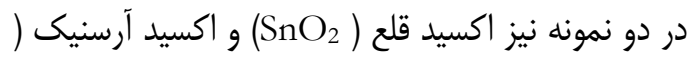
وجود دارد. درصد وزنى اين عناصر براى تمـام نمونههاى آناليز شده به صورت اكسيد در جدول بـ ارائهـ

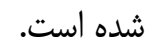
باتوجه به جدول r مشاهده مىشود كه تركيبات عمده

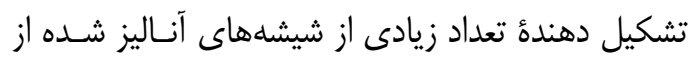

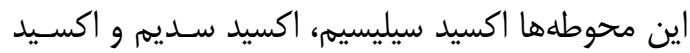

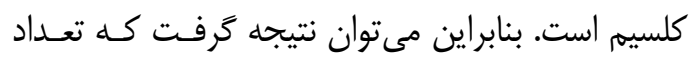
قابل توجهى از شيشههاى آناليز شده از اين محوطههــا

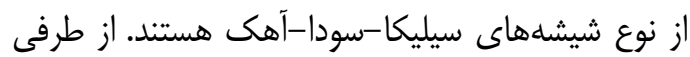
همان طور كه در اين جدول ديده مىشود در تعداد قابل سيل

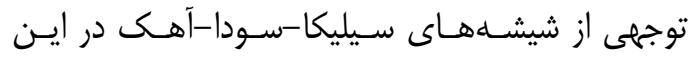

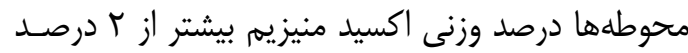

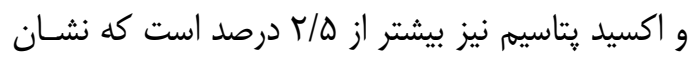
مى دهد در اين نمونهها، منبع تأمين اكسيد سديم كه بله

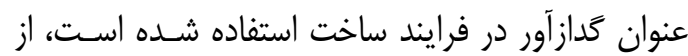

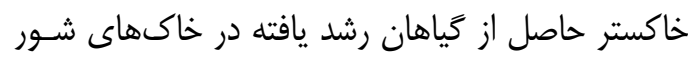

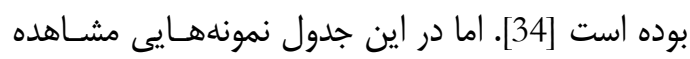

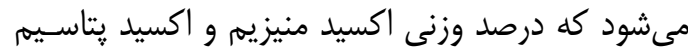
كمتر از ه/ادرصد است كه اين نمونهها، از نوع شيشه أنس

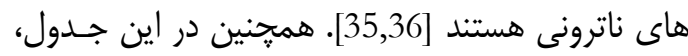

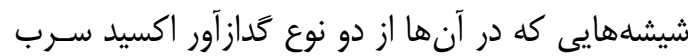


آهك قرار مى گيرد [39]. بنابر اين ايـن آنـاليزهـا نشـان

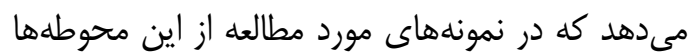

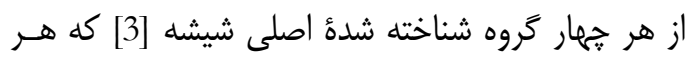
كدام متعلق به جغرافياى مشـخص و شــاحته شـدهاى است حداقل يك نمونه يافت شده است.
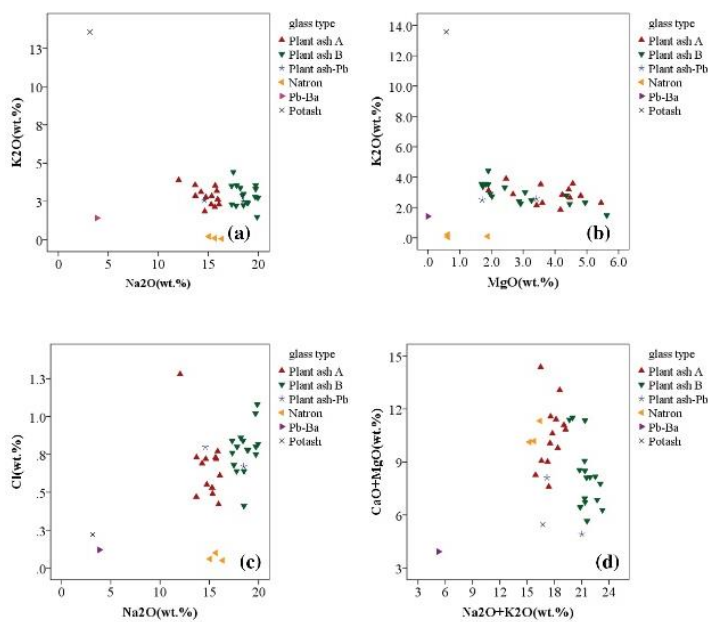

شكل س: a- تغييرات درصد وزنى اكسيد سديم بر حسب اكسيد

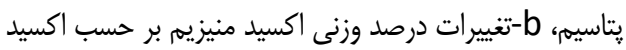

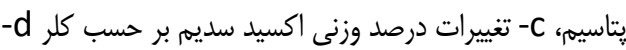

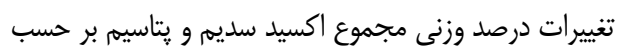

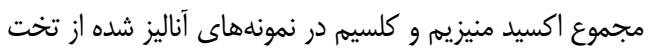

$$
\text { سليمان و اردبيل. }
$$

Fig 3: Scatter plot in wt.\% of (a): sodium oxide $\left(\mathrm{Na}_{2} \mathrm{O}\right)$ versus potassium oxide $\left(\mathrm{K}_{2} \mathrm{O}\right)$, (b): magnesium oxide $(\mathrm{MgO})$ versus potassium oxide $\left(\mathrm{K}_{2} \mathrm{O}\right)$, (c): sodium oxide $\left(\mathrm{Na}_{2} \mathrm{O}\right)$ versus chlorine, (d): total of sodium oxides and potassium oxides in terms of total of magnesium oxides and calcium oxides, in analyzed samples from Takht-e Suleiman and Ardabil.

براى مشخص شدن بهتر و دقيقتر شيشههاى نـاترونى

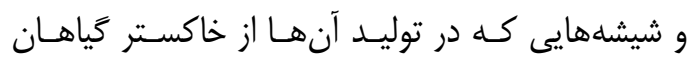

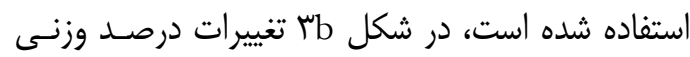

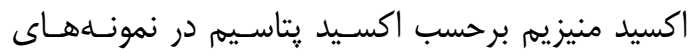

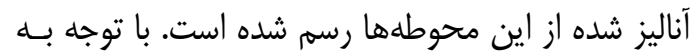

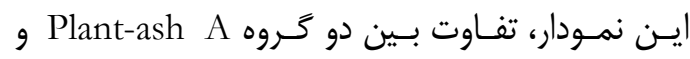

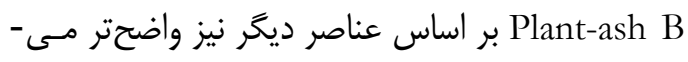
شود. همانطور كه در ايـن شـكل مشـخص اسـت در كروه Plant-ash A مقدار اكسيد منيزيم تقريباً در تمام

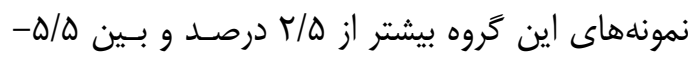

از نوع شيشههاى سيليكا-سودا-آهك است كه اين نوع

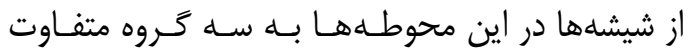

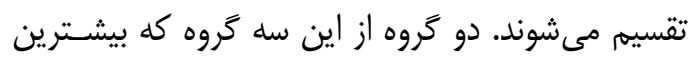

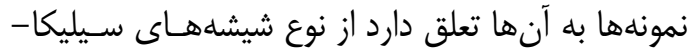
سودا-آهى است كه از خاكستر كَياهان به عنوان مـاده

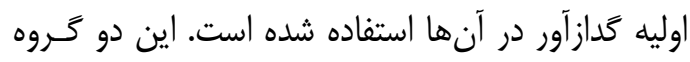

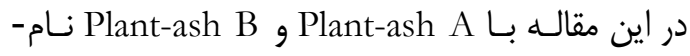

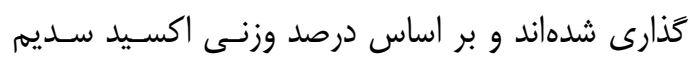

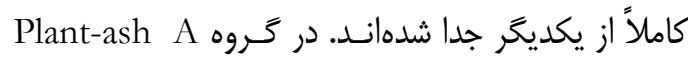

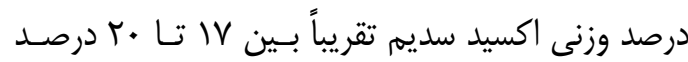

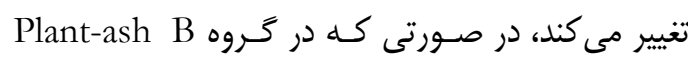

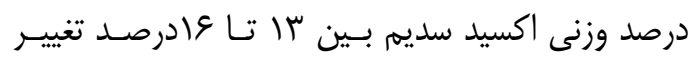

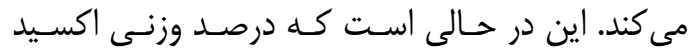

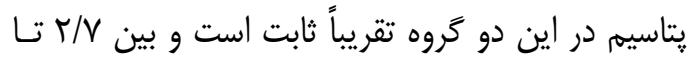

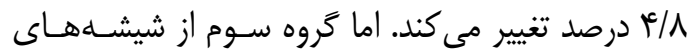

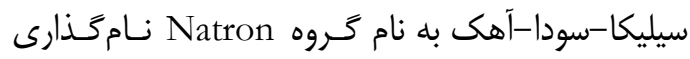

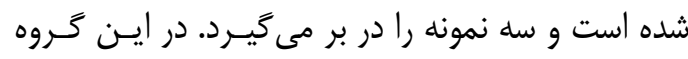

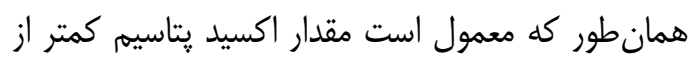

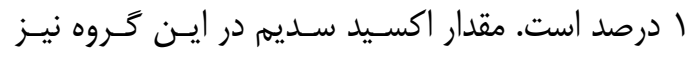

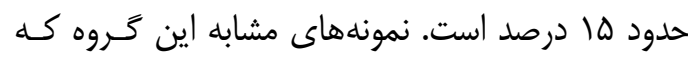

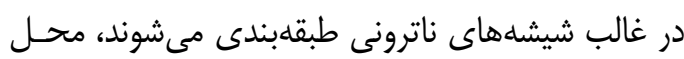

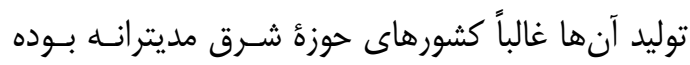

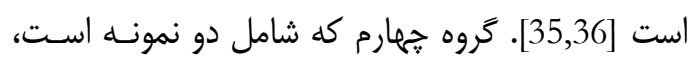

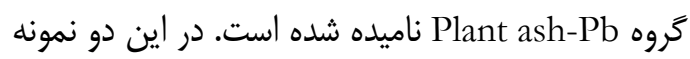

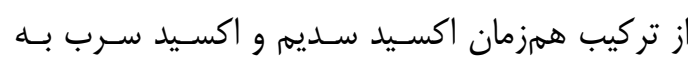

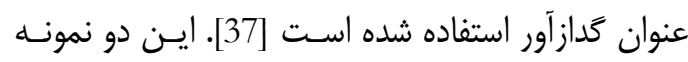

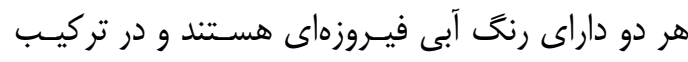

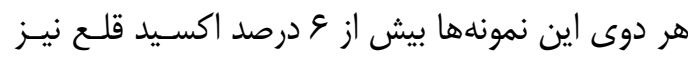

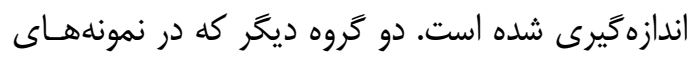

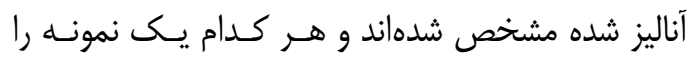

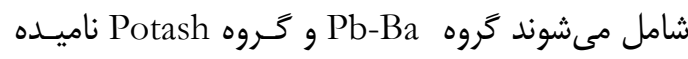

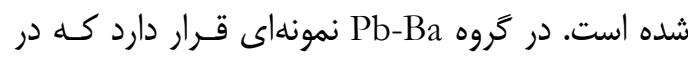

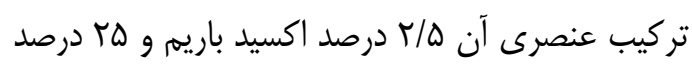

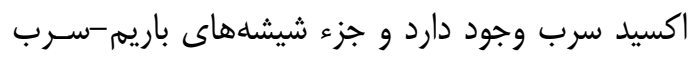

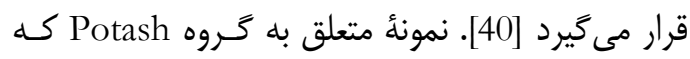
حدود عال درصد اكسيد يتاسـيهم در تركيـب آن انــازهـ

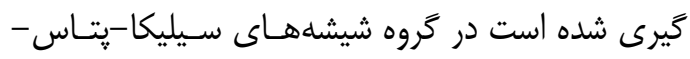


اين مناطق تاريخى وارد شده باشـــ [42]. همجنــــن بـاــا

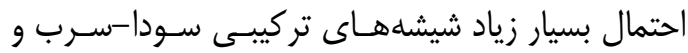

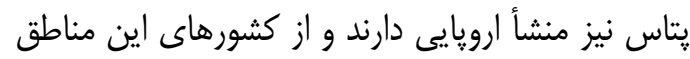

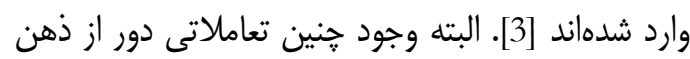
نيست و مىتوانسته از طريق جاده ابريشم كـه از حـوزئ

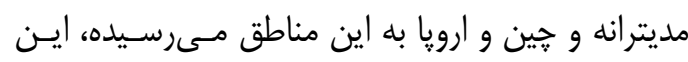
كار را تسهيل كند [43].

\section{r-ه. بررسى تغييرات و تنوع منابع سيليس}

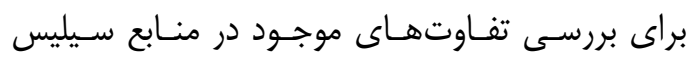
استفاده شده در مصنوعات شيشـهاى ايـن محوطـهـهـا،

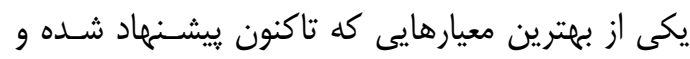

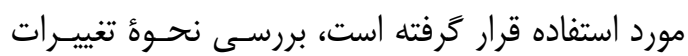

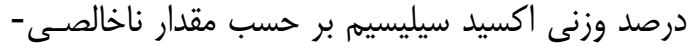

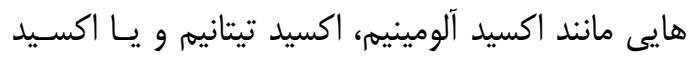

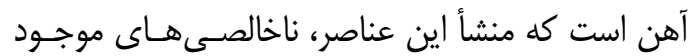
درماده اوليئ سيليس است [44,5].

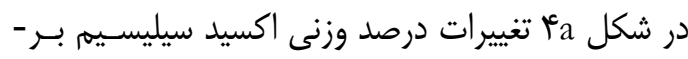

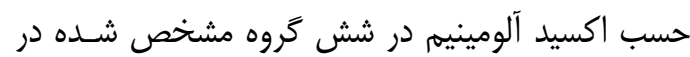

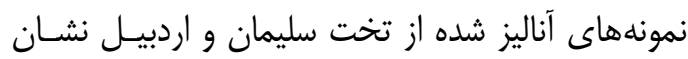
داده شده است. بر اساس اين نمودار، روند كلى تغييرات

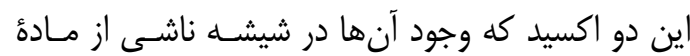
اوليه سيليس است، براى تمام نمونههاى آناليز شده كه

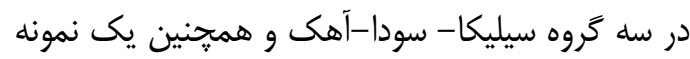

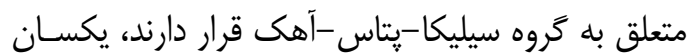
است. تنها جهار نمونه از اين روند كلى تغييرات ييـروى

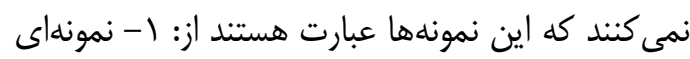
كه در آن درصد وزنى اكسيد آلومينيم بسيار زياد است و

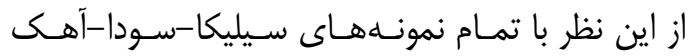

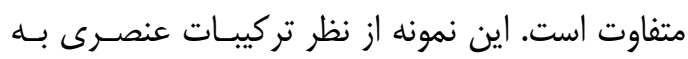

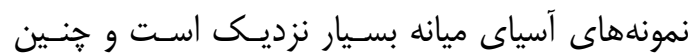
نمونههاى شيشه با درصد آلومينيم بالا از مناطقى مانند

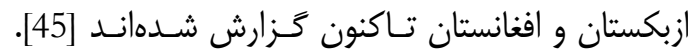
همجنين سه نمونهٔ ديخر نيز متعلق به كروههاى

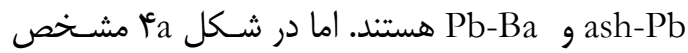
است كه خلوص سيليس در نمونهاى متعلق به خـروه-

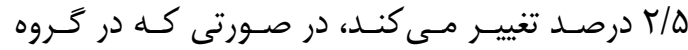
Plant-ash B منيزيم بين ץ-ץ درصد است و فقـط در أ نمونسه مقــدار آن بين و-4 درصد است. اين تفـاوت واضـح و آشـكار

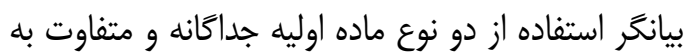
عنوان كدازآور در ساخت نمونـهـهـاى ايـن محوطـهـهـا

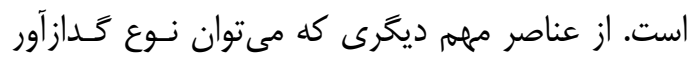

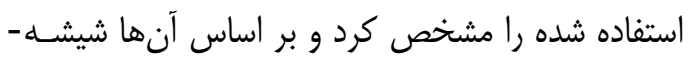

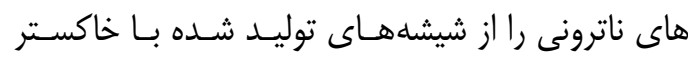

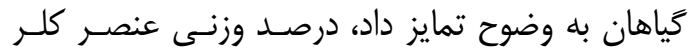

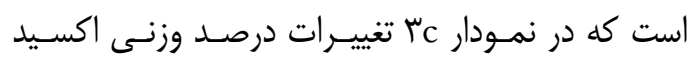
سديم بر حسب كلــر نشـان داده شــــ اسـت. تغييـرات

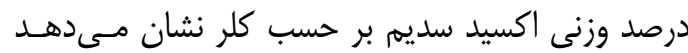

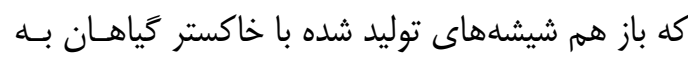

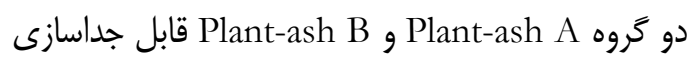

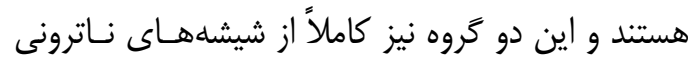
قابل تفكيك هستند. بررسى هاى انجام شده، نشان داده

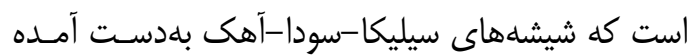
از خاكستر گياهان داراى ناخالصى كلر زياد و نمونههاى

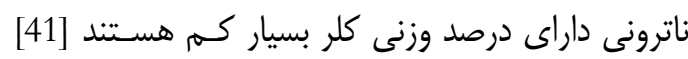

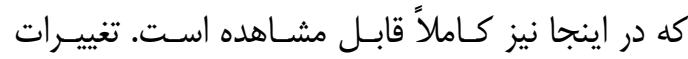
عناصر قليايى كه شامل مجموع اكسيد سديم و يتاسـيم

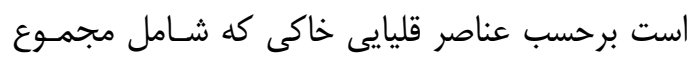

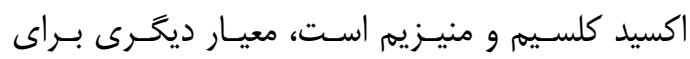
بررسى نوع كدازآرور استفاده شده در شيشه است. نمودار

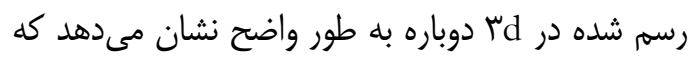

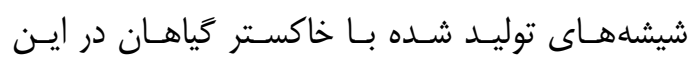
محوطهها به دو گروه متمايز تقسيم شدهاند. همجنين بر اساس اين نمودارها وجود برخى از نمونه-

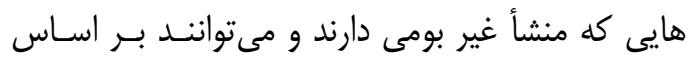

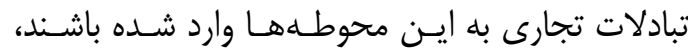
كاملاً مشخص و تأييد مى شود. به عنوان منان مثال تركيبات

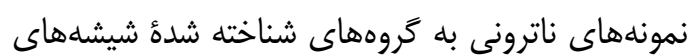

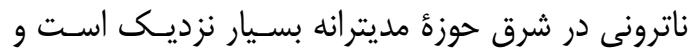

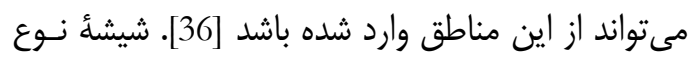

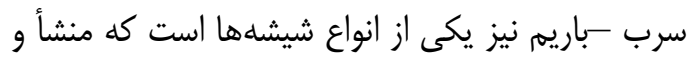

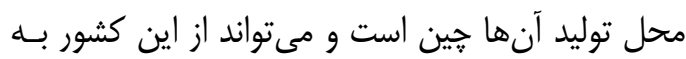


همبستخگى بين اين دو ناخالصى، بــراى نمونسهـــاى دو

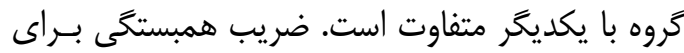

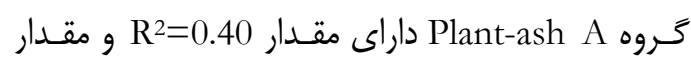

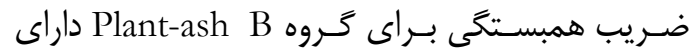

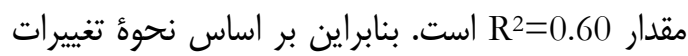
بين عناصر مرتبط با سيليس در نمونههاى آناليز شده از اين محوطهها، مىتوان نتيجه كيرى كرد كه شيشهای اين دو گروه بر اساس ماده اوليه سيليس نيز احتمـالاً از

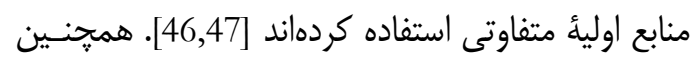

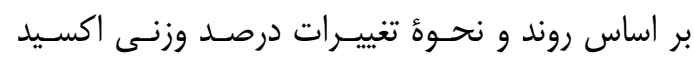

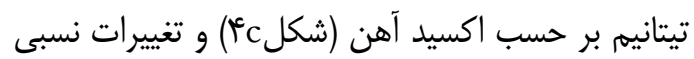
اكسيد آهن به اكسيد آلومينيم برحسب تغييـرات نسـبـ اهنى

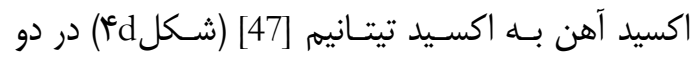

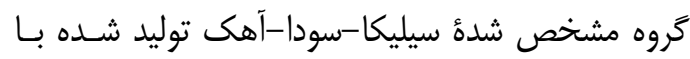

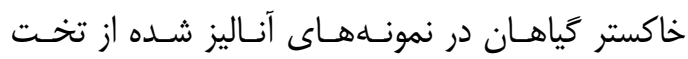
سليمان و اردبيل، استفاده ازمنابع متفاوت سيليس دوباره تأييد مى شود.
Potash و Natron آناليز شده از اين محوطهها است. در نمونههاى ناترونى

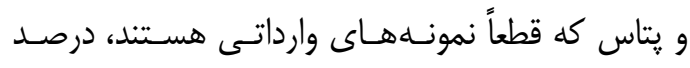

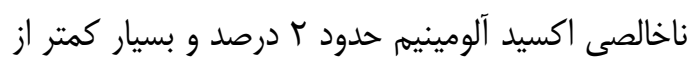

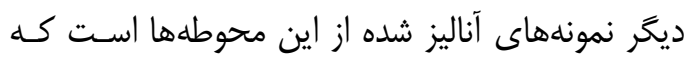
اين ناخالصى بين r تا و درصد تغيير مى كند. اما با توجه به اينكه تعداد زيـادى از نمونـههــاى آنـاليز

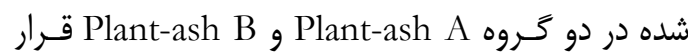
دارند و مشاهده شد كه در نمونههـاى ايـن دو تـروه از

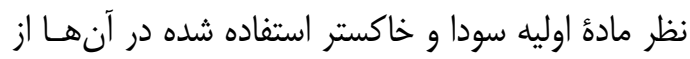

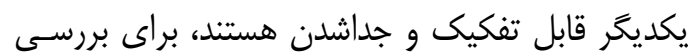
بهتر كيفيت سيليس و تغييرات موجود در آن، نمونههاى بكاي

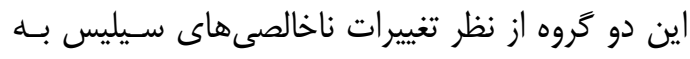

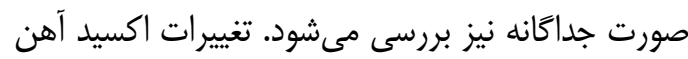

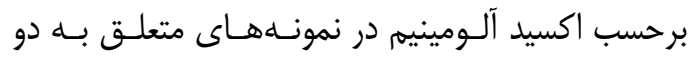
گروه Plant-ash A و شكل Plant-ash است. اين نمودار نشان مىدهد كه بين ايسن دو اكسـيد

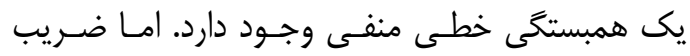
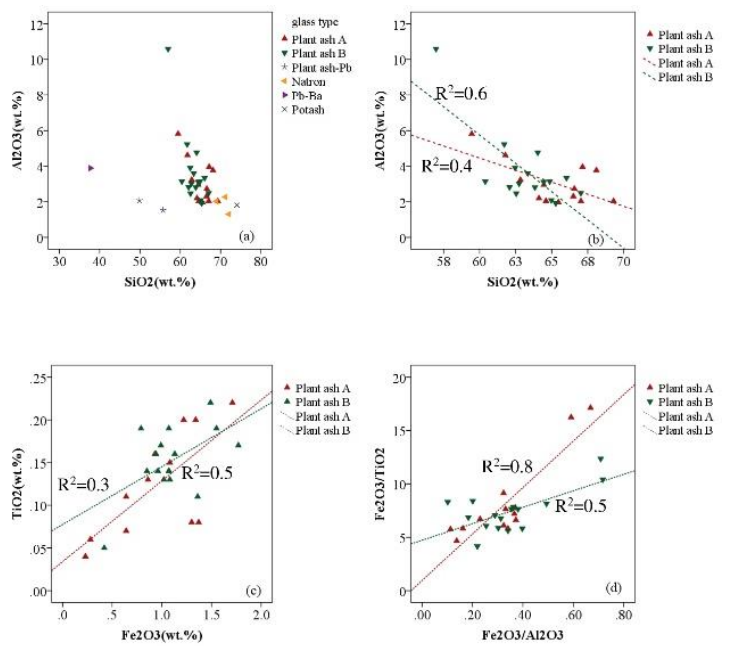

شكل f: a-تغييرات درصد وزنى اكسيد سيليسيم بر حسب اكسيد آلومينيم در شش كروه مشخص شده در نمونههاى آناليز شده، b-تغييرات درصد

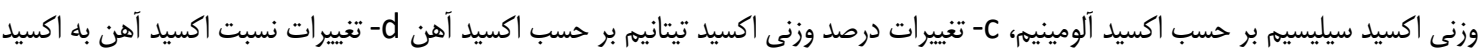

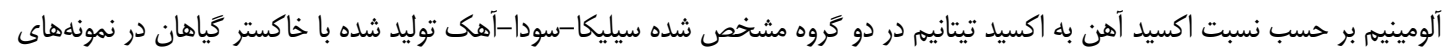

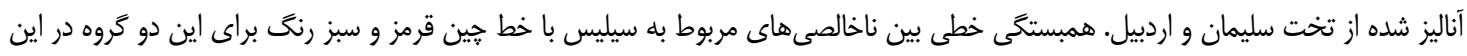
شكل نشان داده شده است.

Fig. 4: (a): Scatter plot in wt.\% of silicon oxide $\left(\mathrm{SiO}_{2}\right)$ in terms of aluminum oxide $\left(\mathrm{Al}_{2} \mathrm{O}_{3}\right)$ in the 6 groups identified in the analyzed samples, (b): Scatter plot in wt.\% of silicon oxide $\left(\mathrm{SiO}_{2}\right)$ in terms of aluminum oxide $\left(\mathrm{Al}_{2} \mathrm{O}_{3}\right)$, (c): Scatter plot in wt.\% of titanium oxide in terms of iron oxide (d): Scatter plot in wt. $\%$ of ratio of iron oxide to aluminum oxide in terms of the ratio of iron oxide to titanium oxide, in the two identified groups of plant- ash silica-soda-lime in analyzed samples from Takht-e Soleiman and Ardabil. The linear correlation between silica impurities is shown in this figure with red and green dash lines in two groups. 
كنندة متفاوتى مانند اكسيد منكَنز يا اكسيد آنتيمون و يا تركيب اين دو اكسيد استفاده مى كردند [48]. اما همان طور كه در تصاوير إيتيكى نمونسهـــاى آنـاليز

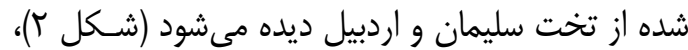
در شيشهاى اين دو محوطه علاوه بر رنخـهـاى سـبز

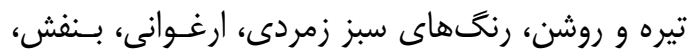
سياه، قهوهاى و آبى فيروزهاى نيز مشـاهده مسى شـــندا. بنابر اين در اين بخش نقش عناصـر مختلـف در ايجـاد جنين رنغَهاى متنوع در اين شيشهها و عامـل ايجـاد

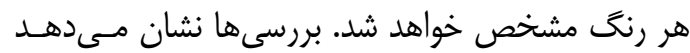

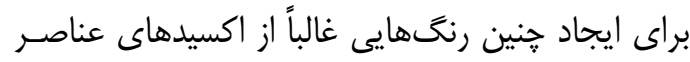

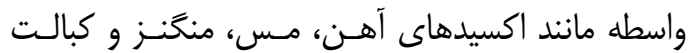

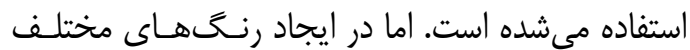

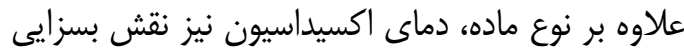

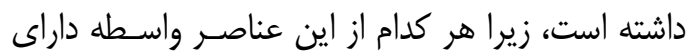
عدد اكسايش مختلفى هستند كه در دماهـاى مختلفى إسى اكسيد مىشوند و با تغيير دما، مىتوان با استفاده از يك

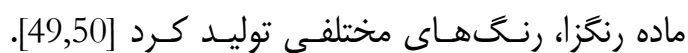

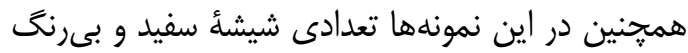

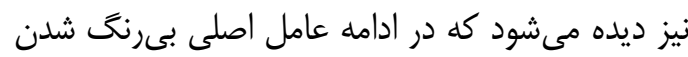
اين شيشهها نيز بررسى خواهد شد [50,51].

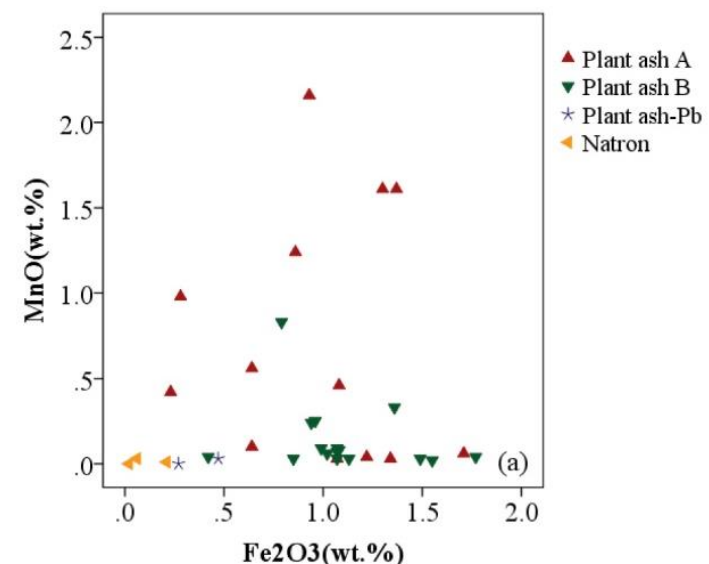

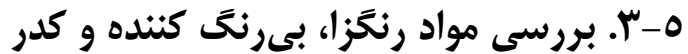
كنتده

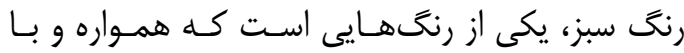
فراوانى بسيار زياد در شيشههاى تـاريخى كـه از دورههاى مختلف بهدست آمدهاند، مشاهده مسى شـود. علـت اصلى ايجاد اين طيف رنغى در شيشههاى تاريخى، بـه

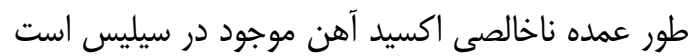
و اين رنخ تقريباً در تمام نمونههايى كه از شن و ماسه به عنوان ماده اوليه سيليس استفاده كردهاند، وجود دارد. بنابراين اكسيد آهن به صـورت ناخواسته در تركيبـات

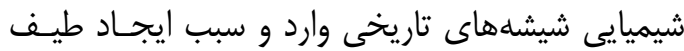

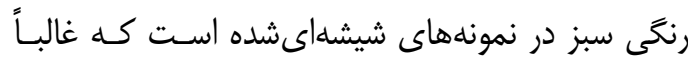

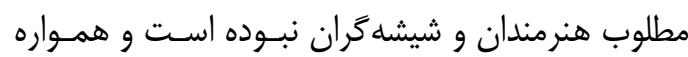

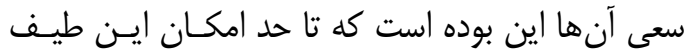
رنكى را با افزودن موادى به نام رنخبر از بين ببرند [2].

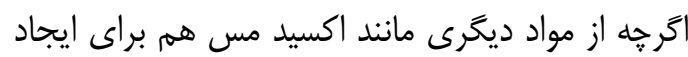
رنح سبز در شيشهها استفاده مى شود كه در اين مـوارد اين مادهٔ رنخزا به صـورت عمـــى وارد فراينـد سـاخت

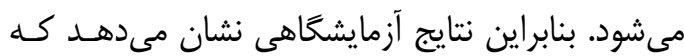

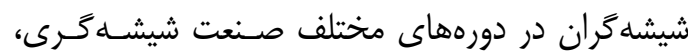
براى از بين بردن رنخَهاى ناخواسته در شيشه و ايجاد

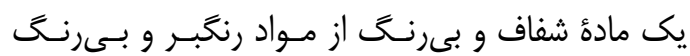

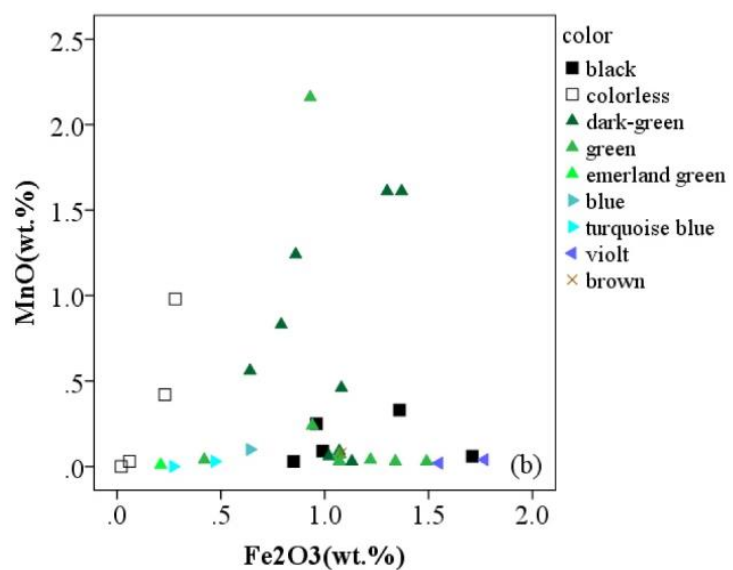

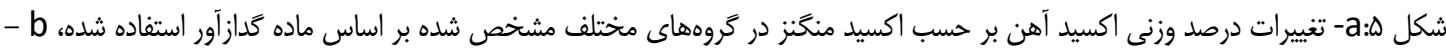

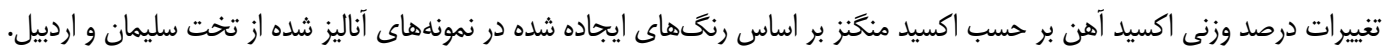
Fig.5: Scatter plot in wt.\% of (a): iron oxide $\left(\mathrm{Fe}_{2} \mathrm{O}_{3}\right)$ in terms of manganese oxide (MnO) in different groups determined based on the flux, (b) iron oxide $\left(\mathrm{Fe}_{2} \mathrm{O}_{3}\right)$ in terms of manganese oxide $(\mathrm{MnO})$ based on color of analyzed samples from Takht-e Suleiman and Ardabil. 
غيرعمد در شيشهها بــه عنـوان مـواد رنخــزا وارد شـــه

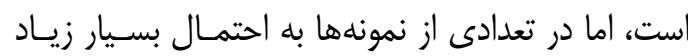

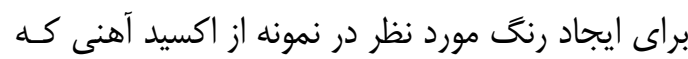

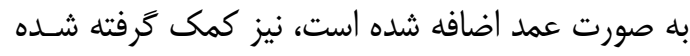

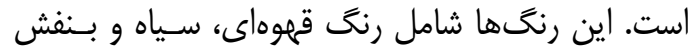
هستند كه يكى از عناصرى كه سبب ايجاد جنين رنكى رنى

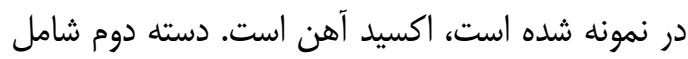

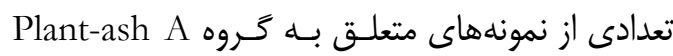

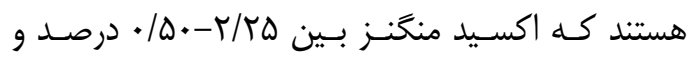

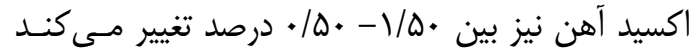

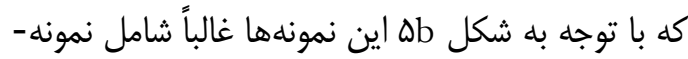

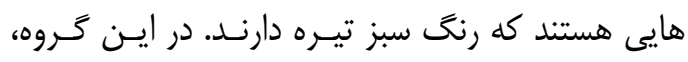
مادهُ رنخَبر به صورت عمدى وارد شده است ولى مـاده رنگزاى اكسيد آهن باز هم غيرعمد استفاده شده است.

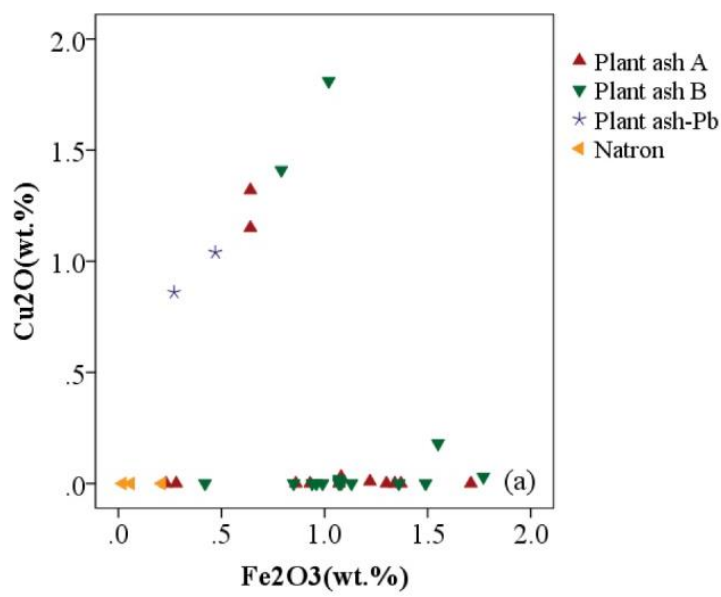

در شكل Da تغييرات اكسيد آهن برحسب اكسيد منَنز

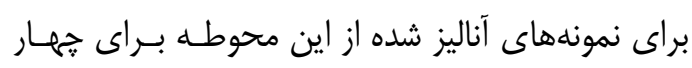
گروه مختلف مشخص شده بر اساس نوع شيشهها و در

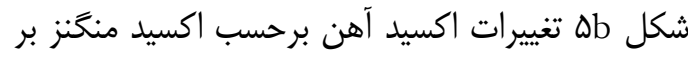

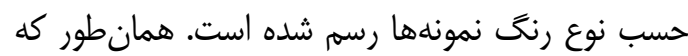
در شكل Da مشاهده مى شود، بر اساس تغييرات ميـزان اكسيد آهن برحسب اكسيد منَّنز، نمونههاى آناليز شده از اين محوطه به دو دستغ عمده تقسيهم مىشوند: دستأ اول نمونههايى هستند كه در آنها مقدار اكسيد منگنـز

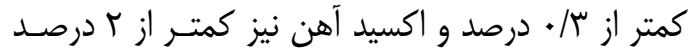

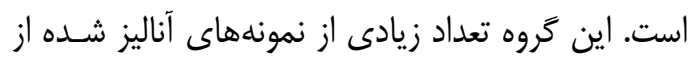

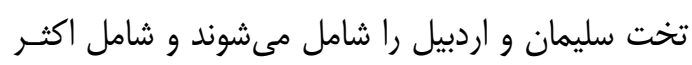
رنَّها نيز هستند. اين تغيير ناخالصىها به ايسن معنسى

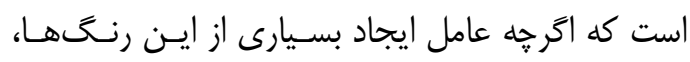

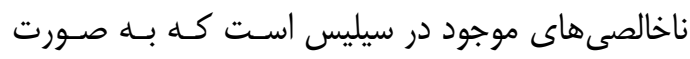

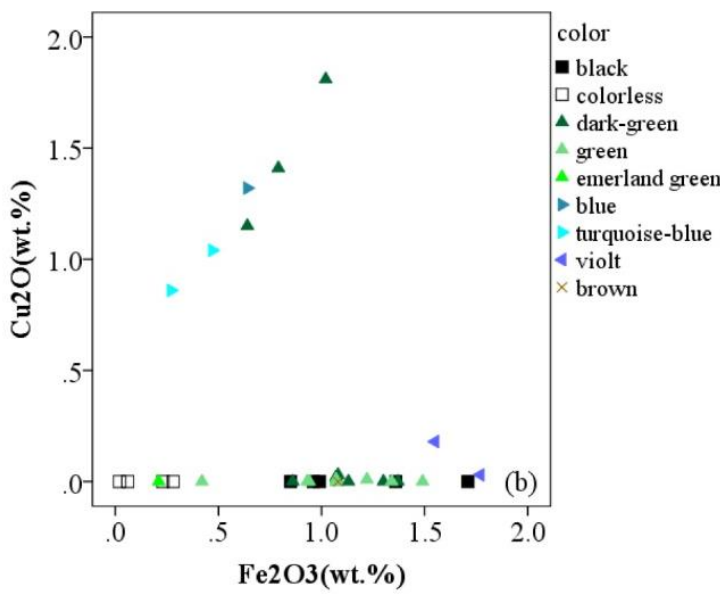

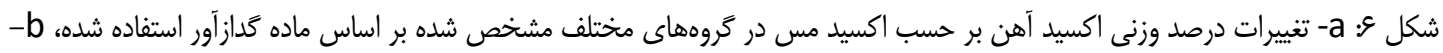

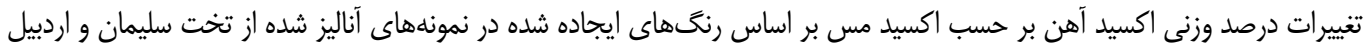
Fig.6: Scatter plot in wt.\% of (a): iron oxide $\left(\mathrm{Fe}_{2} \mathrm{O}_{3}\right)$ in terms of copper oxide $\left(\mathrm{Cu}_{2} \mathrm{O}\right)$ in different groups determined based on the flux, (b) iron oxide $\left(\mathrm{Fe}_{2} \mathrm{O}_{3}\right)$ in terms of copper oxide $\left(\mathrm{Cu}_{2} \mathrm{O}\right)$ based on color of analyzed samples from Takht-e Suleiman and Ardabil.

در اين شكلها نشان داده شده است، مشخص است كه

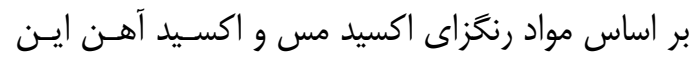
نمونه ها به سه دستأ عمده تقسيم مسى شـوند. در دسـتأه اول مشاهد مىشود كه اكسيد آهن تنها به عنوان عامل

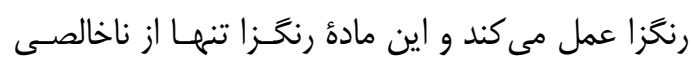
موجود در سيليس ناشى نمى شود و در برخى نمونهها به

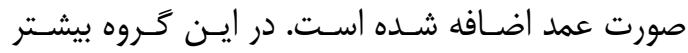

در شكلa a تغييرات درصد وزنى اكسيد آهـن برحسـب

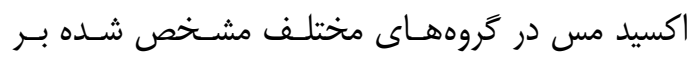

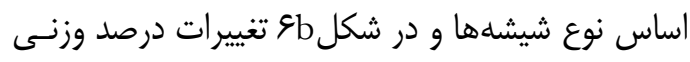

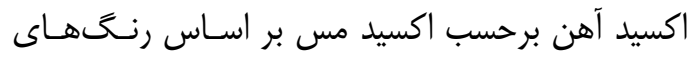

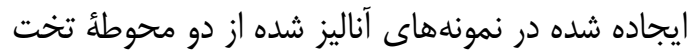

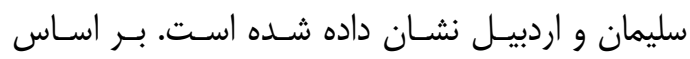

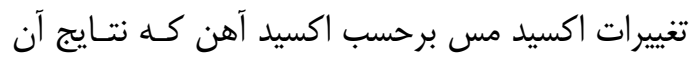


محل توليد و تفــاوت در مــواد اوليـهـ اسـتفاده شـده در

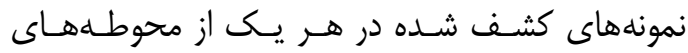

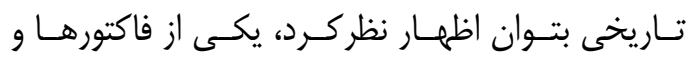
راهكارهاى مهم بررسى تغيـرات درصــ وزنسى اكسـيد آلومينيم برحسب نسبت اكسيد منيزيه به اكسيد كلسيه

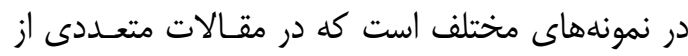
اين رهيافت و مقايسه استفاده شده اسـت [10,43,57]. همان طور كه در مطالب ييشين نيـز اشـاره شـــ مقــدار

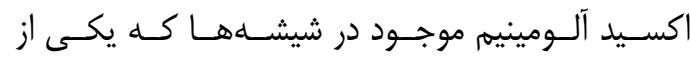
ناخالصىهاى موجود در سيليس اسـت، شـاخص بسـيار

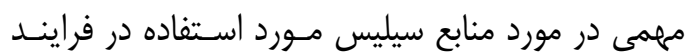
ساخت را نشان مىدهد. همجنين مقدار اكسيد منيزيم و موردي اكسيد كلسيه و نسبت اين دو اكسيد در شيشهها، نشان دهنده ويزگى هاى منابع سوداى مورد استفاده در فرايند ساخت است. در شكل V نتايج مقايسٔ نمونههاى آنـاليز شده در اين يزوهش و نمونههاى آناليز شده از محوطههاى مختلف از عراق، سوريه، فلسطين، مصـر و ايـران نشان داده شده است. بر اساس اين نمودار تركيبات شيشههاى نـوع سـيليكا-

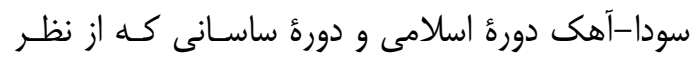
تاريخى بسيار نزديك به شيشههاى اوايل دوره اسلامى

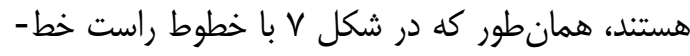

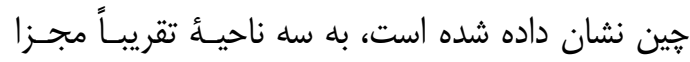

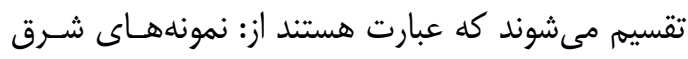

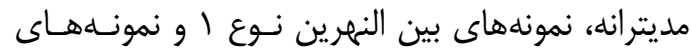

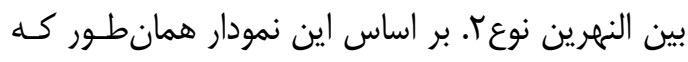

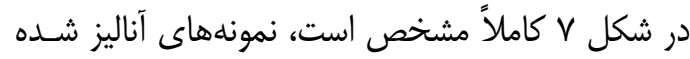

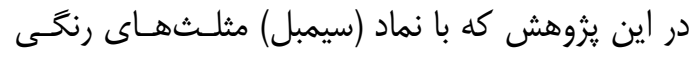
سبز و قرمز نشان داده شدهاند، به طور كامل از نمونـهـ-

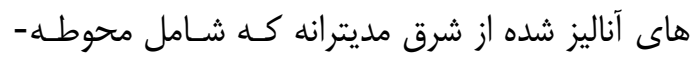

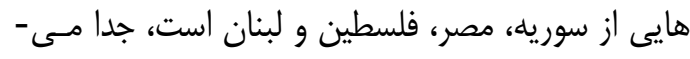

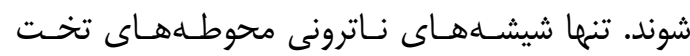
سليمان و اردبيل هستند كه در ناحية مربوط به نمونسهـهاى شرق مديترانه قرار كرفتهاند و كاملاً نيز بـا منشـأ توليد آنها مطابقت دارد. همجنــين در شـكل V كـاملاً

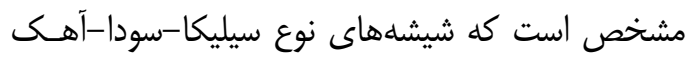

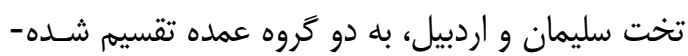

نمونههـاى گ تروه Plant-ash A و Pـ Pرار دارند و شامل نمونههاى سبز، سياه، قهـوهاى و بــفش

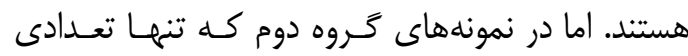
بسيار كمى از نمونهها را شامل مىشـود مقـدار اكسـيد

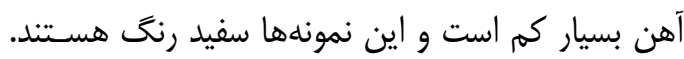

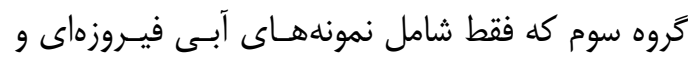
سبز تيره هستند، اكسيد مس به صورت عمد به به خميـرة

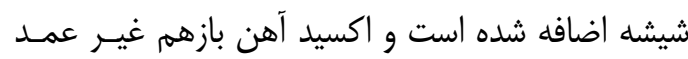

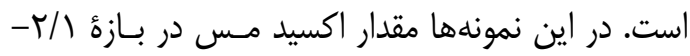
/ • • درصد تغيير مى كند.

\section{ه-ع. بر رسى محل توليـد شيشــهــاى نــوع سيليكا- سودا- آهك بروسي محل}

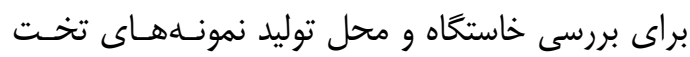

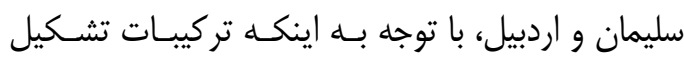

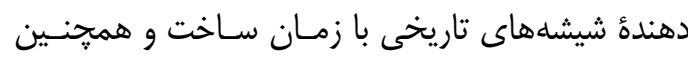

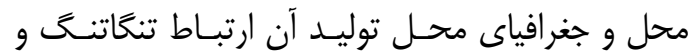

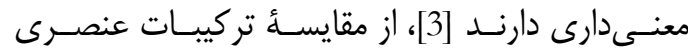

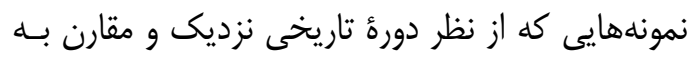

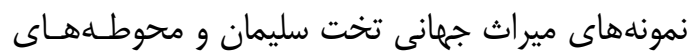

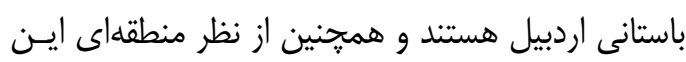

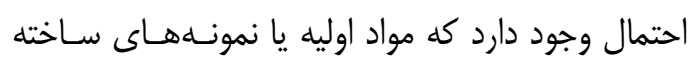

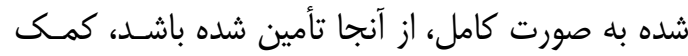

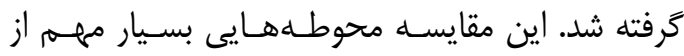

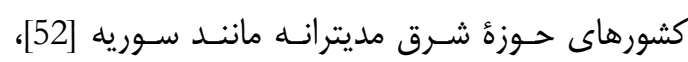
فلسطين [43,53]، لبنان [54] و مصر [7] كه در اوايـل

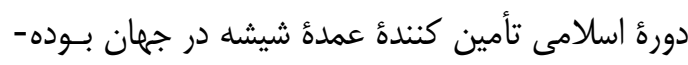

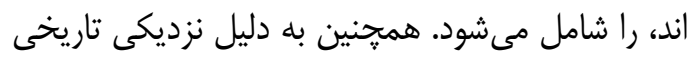

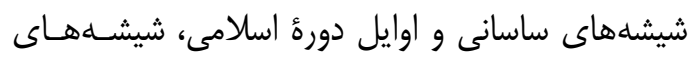

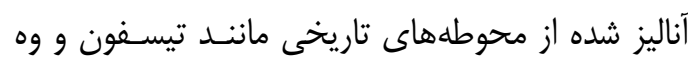

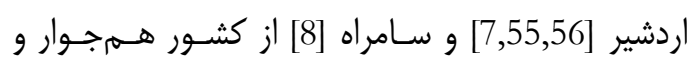
همسايه مانند عراق نيز با نمونههاى اين منطقه مقايسه

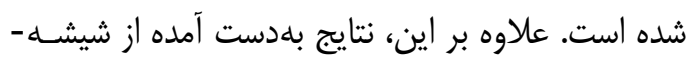

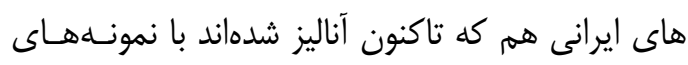

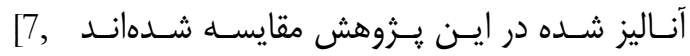

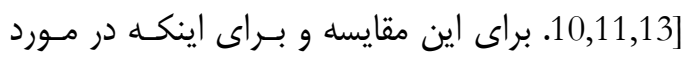


از فرمولاسـيون و مـواد اوليـهـ مــورد اسـتفاده در دورة

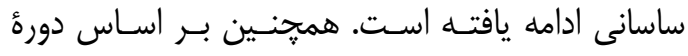

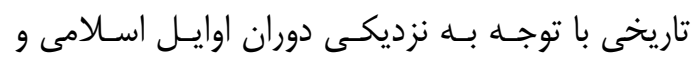

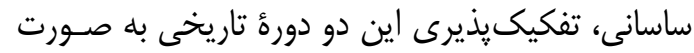

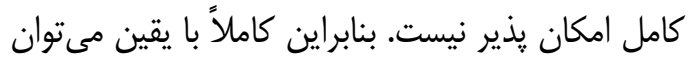

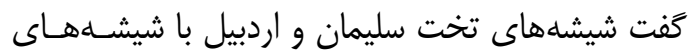
دورة اسلامى در حوزء شرق مديترانه و غالب نمونههاى

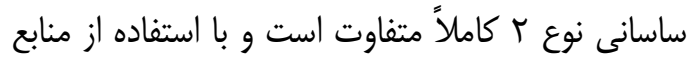

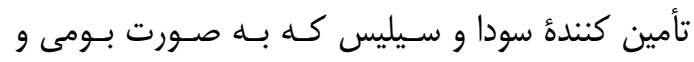
منطقهاى در ايران توليد مىشده است، ساخته شدهانــ،

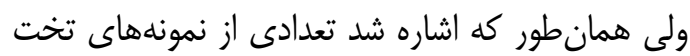

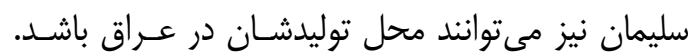

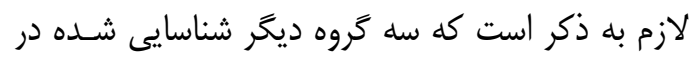
اين يزوهش كه شامل گروه Plant ash-Pb، كروه Ba

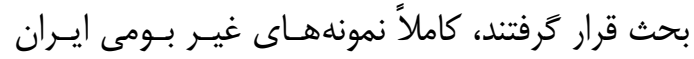

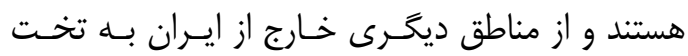

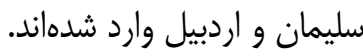

اند و تقريباً تمام نمونههاى آناليز شده از دوره ساسـانى

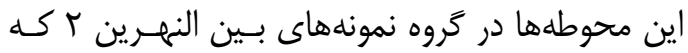

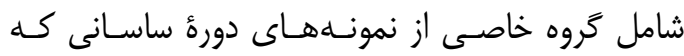
نمونههاى ساسانى نوع r ناميده شدهاند [56] و نمونسههاى اوايل دورة اسلامى از سامره در عراق، قرار كرفتهـ-

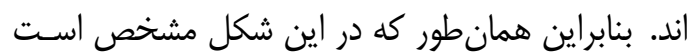
به احتمال زياد محل توليد اين نمونههاى بهدست آمده

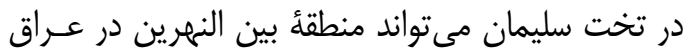

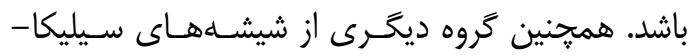
سودا-آهك بلهدست آمده از محوطههاى مـورد مطالــه در اين يزوهش در ناحيهاى قرار كَرفتهاند كه در شـكل

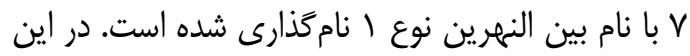

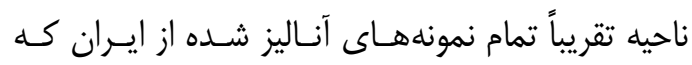

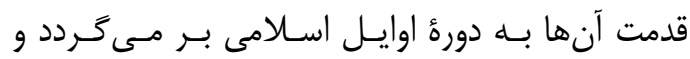

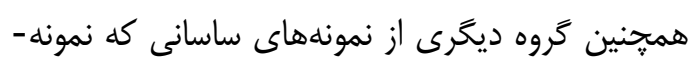

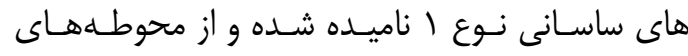

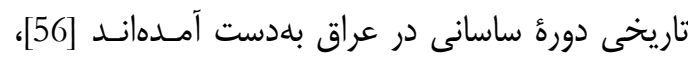
قرار كرفتهاند. البته نزديكى تركيبات سازندة ائن اين نمونه

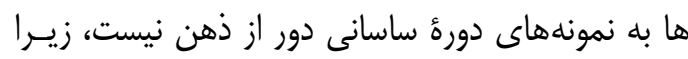

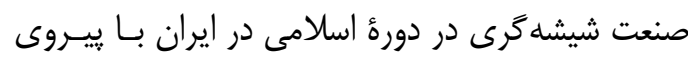

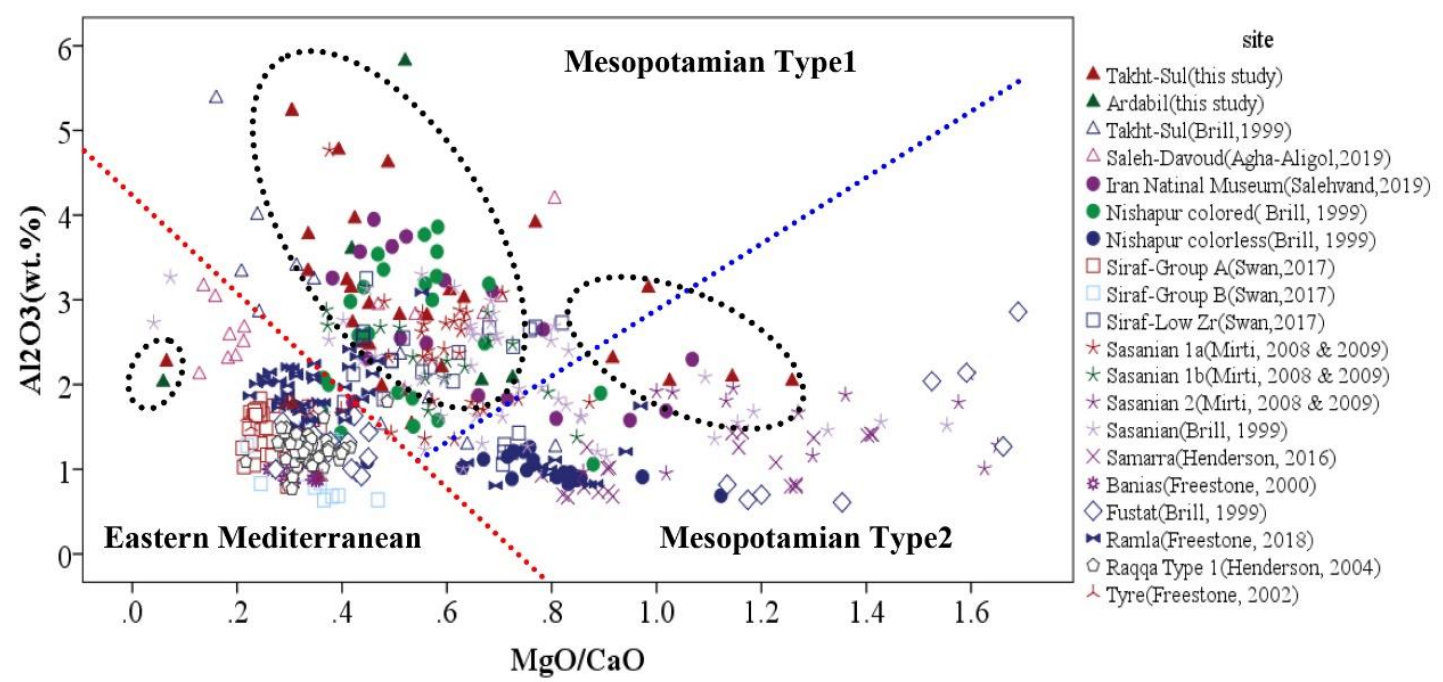

شكل V: تغييرات درصد وزنى اكسيد آلومينيم برحسب نسبت اكسيد منيزيهم به اكسيد كلسيم در تمام نمونههاى آناليز شده در اين يثوهش و مقايسه

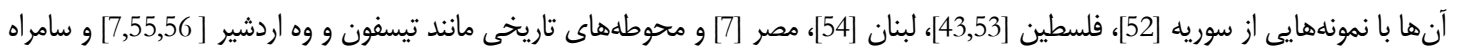

[8] از كشور عراق و همجنين برخى از محوطههاى تاريخى ايران [17,

Fig.7: Scatter plot in wt.\% of aluminum oxide $\left(\mathrm{Al}_{2} \mathrm{O}_{3}\right)$ in terms of the ratio of magnesium oxide( $\left.\mathrm{MgO}\right)$ to calcium oxide $(\mathrm{CaO})$ in all analyzed samples in this study and their comparison with samples from Syria [52], Palestine [43, 53], Lebanon [54],

Egypt [7] and few historical sites such as Ctesiphon and Ve Ardashir [7, 55, 56] and Samarra [8] from Iraq as well as some historical sites in Iran [7, 10, 13,11]. 


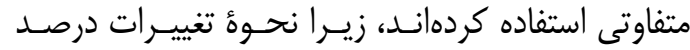

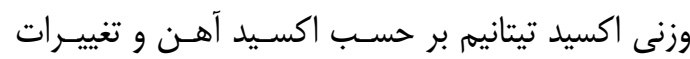

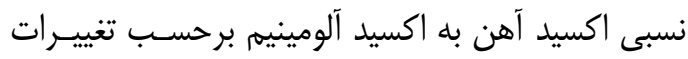

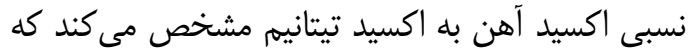

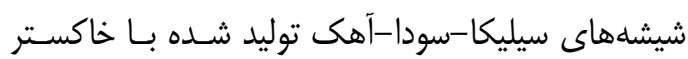

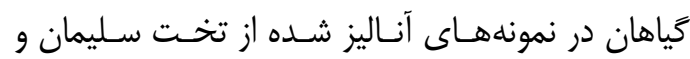

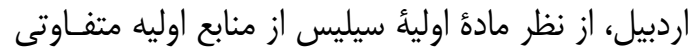

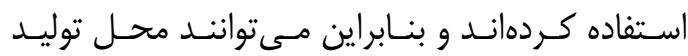
كَوناكونى داشته باشند. علاوه بر اين در بررسى عناصر مختلف كه عامل ايجاد رنخهاى متنوع در اين شيشهها شدهاند مىتوان نتيجه

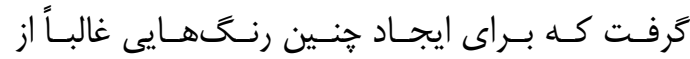
اكسيدهاى عناصر واسطه مانند اكسيدهاى آهن، مـس، منَّنز و كبالت استفاده شده است.

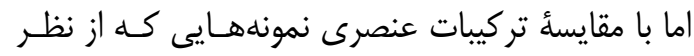

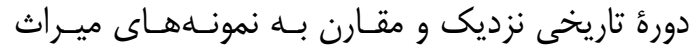

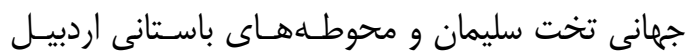

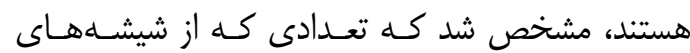

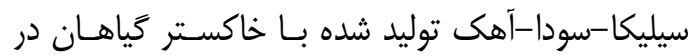

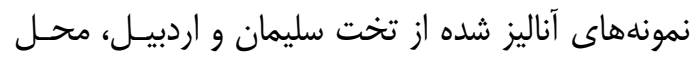

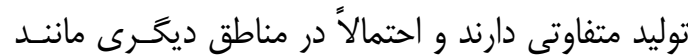

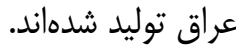

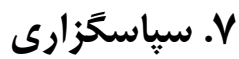

با توجه به اينكه تمام آناليزهاى مورد نياز بـراى انجـام

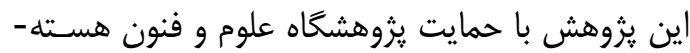

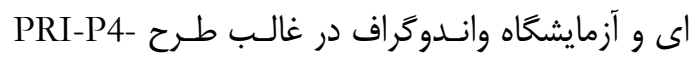
98-002 انجام شده است، نويسندكان بر خود لازم مى -

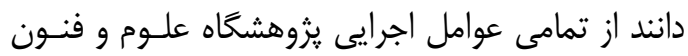

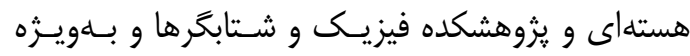

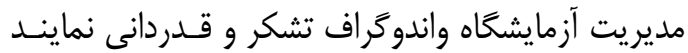

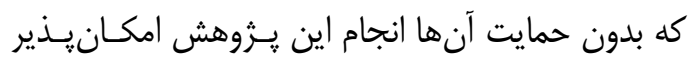
نبود.

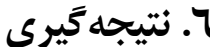

اين يزوهش، به دنبال باسخگَويى به برخى از سئوالات اساسى در مورد فرايند ساخت مصنوعات شيشهاي ايران

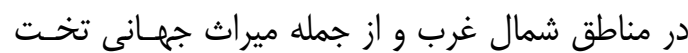
سليمان و محوطههــاى باسـتانى اردبيـل بـود. اولـين و و

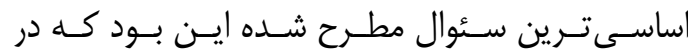

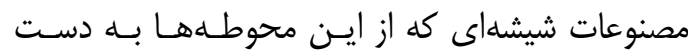

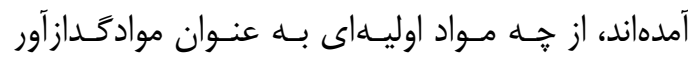

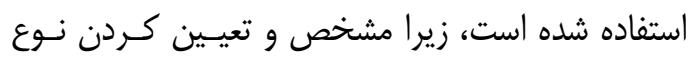

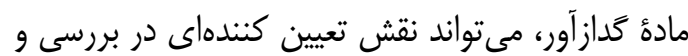
مطالعهُ فرايند تجارت و نقل و انتقالات مواد اوليئ شيشه

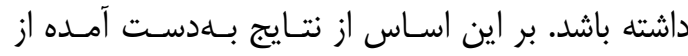

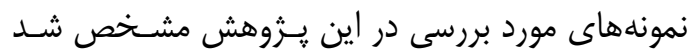
كه شيشههاى آناليز شده از اين محوطه از نظر تركيبات عنصرى بسيار متفاوت هستند و در جندين گرقوه متمايز قرار مى گيرند. بر اساس نوع گدازآور استفاده شده، اكثـر

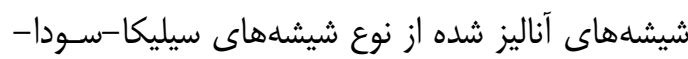

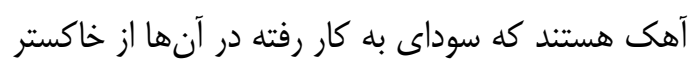
كياهان تهيه شده است. همجنـين در ايسن محوطـهـهـا

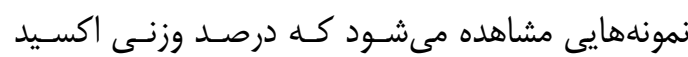

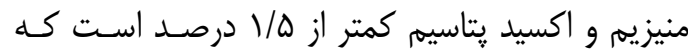
اين نمونهها، از نوع شيشههاى ناترونى هستند. شيشـهـ-

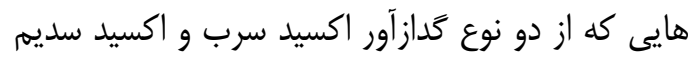

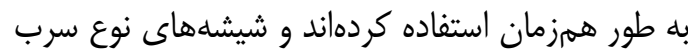

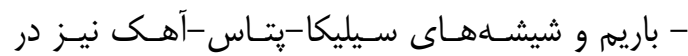
مجموعأ آناليز شده شناسايى شدند. بنابراين بـر اسـاس سئس

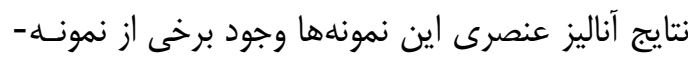

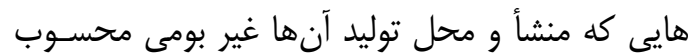

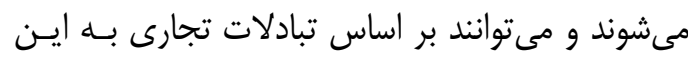
محوطهها وارد شده باشند كاملاً تأييد مى شود. همجنين بر اساس نحؤ تغييرات بين عناصر مـرتبط بـاسـا

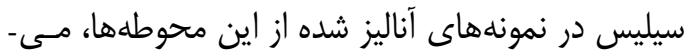
توان نتيجه گيرى كرد كه شيشههاى نوع سيليكا-سودا-

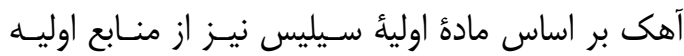




\section{References}

[1] Moorey PR. Ancient mesopotamian materials and industries: the archaeological evidence. Clarendon; 2013.

[2] Henderson J. Ancient glass: an interdisciplinary exploration. Cambridge University Press; 2013.

[3] Rehren T, Freestone IC. Ancient glass: from kaleidoscope to crystal ball. Journal of Archaeological Science. 2015;56:23341.

[4] Lin Y, Liu T, Toumazou MK, Counts DB, Kakoulli I. Chemical analyses and production technology of archaeological glass from Athienou-Malloura, Cyprus. Journal of Archaeological Science: Reports. 2019; 23:700-13.

[5] Oikonomou A, Triantafyllidis P. An archaeometric study of Archaic glass from Rhodes, Greece: Technological and provenance issues. Journal of Archaeological Science: Reports. 2018;22:493-505.

[6] Whitehouse D. 'Things that travelled': the surprising case of raw glass. Early Medieval Europe. 2003;12(3):301-5.

[7] Brill RH, Stapleton CP. Chemical analyses of early glasses: volume 3: the years 2000-2011, reports, and essays. Corning Museum of Glass. 2012.

[8] Henderson J, Chenery S, Faber E, Kröger J. The use of electron probe microanalysis and laser ablationinductively coupled plasma-mass spectrometry for the investigation of 8th14th century plant ash glasses from the Middle East. Microchemical Journal. 2016; 128:134-52.

[9] Wypyski MT. Chemical analysis of early Islamic glass from Nishapur. Journal of Glass Studies. 2015:121-36.

[10] Swan CM, Rehren T, Lankton J, Gratuze B, Brill RH. Compositional observations for Islamic glass from Sīrāf, Iran, in the Corning Museum of Glass collection. Journal of Archaeological Science: Reports. 2017; 16:102-16.

[11] Salehvand N, Agha-Aligol D, Shishegar A, Rachti ML. The study of chemical composition of Persian glass vessels of the early Islamic centuries (10th- 11th centuries AD) by micro-PIXE; Case Study: Islamic collection in the National Museum of Iran. Journal of
Archaeological Science: Reports. 2020; 29:102034.

[12] Agha-Aligol D, Jafarizadeh M, Moradi M. Micro-PIXE: A Powerful Technique in Measurement and Determination of Raw Materials of Glass Artifacts of Parthian Period from Shaur (Susa). Journal of Research on Archaeometry. 2018;4(1):4765.

[آقا على گل، داود، جعفرى زاده، مسله؛ مرادى، محمود.

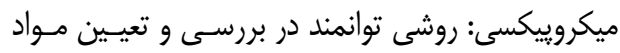
اوليه مصـنوعات شيشـهاى دوره اشـكانى كـاخ شـائور

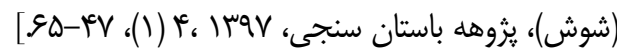

[13] Agha-Aligol D, Jafarizadeh M, Rahbar M, Moradi M. Elemental Composition of Glass Beads Excavated From Saleh Davoud Tombs in Susa by Micro-PIXE: Evidences of Trade of Glass Artifacts during the Parthian Period. Journal of Research on Archaeometry. 2019;5(1):143-66.

[آقا على گلى، داود، جعفرى زاده، مسله، رهبر، مهرى،

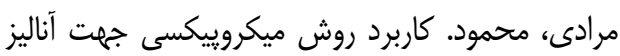
عنصرى مهرههاى شيشاى مكشوفه از آرامخاههاى

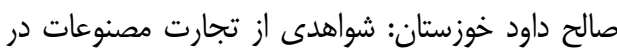

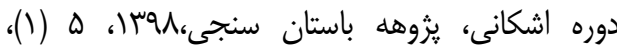
[.199-1)

[14] Agha-Aligol D, Sodaei B, Khosravi L, Karimi M. Investigation and Study of Glass Artifacts of the Sassanid Period; Case Study: Jahangir Dome and Gouriyeh Glasses in Ilam Province using MicroPIXE Technique. Journal of Research on Archaeometry. 2019;5(2):47-70.

[آقا على كل، داود، سودايى، بيتا، خسروى، ليلا، كريمى،

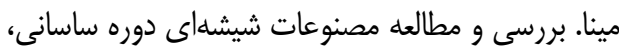

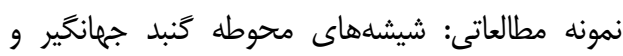

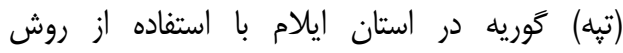

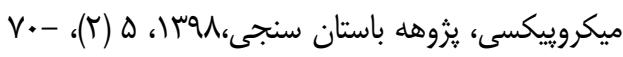

$[.1 \mathrm{~V}$

[15] Bahadori R, Agha-Aligol D. Labratorial Studies on the Blue and Green Beads Used in the Prehistoric Ornaments of National Museum of Iran. pazhoheshhaye Bastan shenasi Iran. 2018; 8(18):45-62.

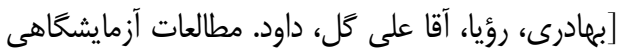

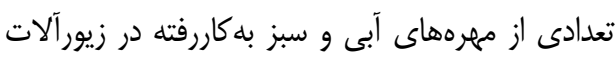


ييشازتاريخ موزه ملى ايران، يزوهشهاى

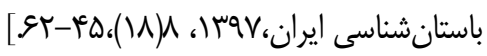

[16] Sarferaz A A, Kiani M Y. Takht-e sulyman. Tabriz, Moaseseh ye Tarikh va Farhang Iran.1347.

[سرفراز، على اكبر و كيانى، محمد يوسف. تخت سليمان،

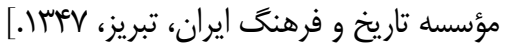

[17] Wiegartz H. Archaologischer Anzeiger.tumulus tepe Majid.1965;788

[18] Naumann R. Die Ruinen von Tacht-e Suleiman und Zendan-e Suleiman und Umgebung. Führer zu archäologischen Plätzen in Iran. 1977.

[19] Wilson J C. History of Iranian art, translated by Masoud Rajbnia, Tehran: bongah tarjomeh va nashre ketab.1356.

[ويلسن، كريستى. تاريخ صنايع ايران، ترجمه مسعود

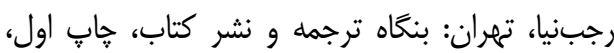

$[.1 \%$ L

[20] Kambakhsh fard S. An inscription of Sabalan mount. Bastanshenasi va honare Iran.1347; 1, 55-9.

[كامبخش فرد، سيفالله. سنى نبشتههايى در اطراف

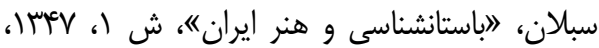

صص Dه تا ه9.

[21] Haerinck E. Painted pottery of the Ardabil style in Azerbaidjan (Iran). Iranica Antiqua. 1978; 13:75.

[هرينگ، ارنى. سفال ايران در دوره اشكانى،

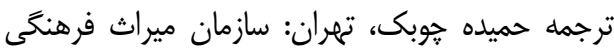

كشور.]

[22] Yousefi H. Site of Qonaq Qiran (ruin dez), national registration file, Ardabil archive of ministry of cultural heritage, handicrafts and tourism. 1381.

[يوسفى، حسن، قلعه قوناخ قيران(رويين دز)، يرونده

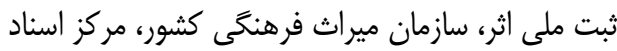

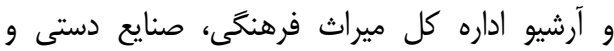

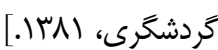

[23] Yousefi H. Site of shahar yeri and mekteb oshaglari, national registration file, Ardabil archive of ministry of cultural heritage, handicrafts and tourism.1381.

]يوسفى، حسن، محوطه باستانى شهريرى و مكتب

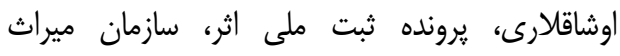

فرهنگىى كشور، مركز اسناد و آرشيو اداره كل ميراث

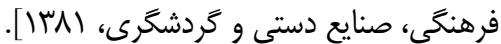

[24] Deravianco A, Zedi M, Zenin A, Gladishu S, Shapkin A. Archaeological study report of the joint expedition of Russia and Iran, on the southern shores of the Caspian Sea, Omal-Banin Ghafori, Tehran: moalef, moaseseh ye binal melel yeh motaleate gerdesh geri vehsht mina. 1392; 4, 7-22.

[درويانكو، آناتولى، زيدى، محسن، زنين، آناتولى،

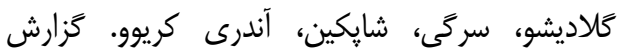
بررسى باستانشناختى هئيت مشترك روسيه- ايران در درين،

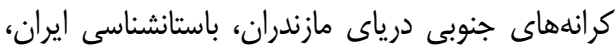
به كوشش امالبنين غفورى، تهران: مؤلف، مؤسسه بينالمللى مطالعات كردشگرى وهشت مينا، ش أ، سال

جهlpa

[25] Burney CA. Meshkin shahr in Iran, 1979; 156-5.

[26] Ferdowsi A G. Shahnameh Ferdowsi, Mashhad: Sokhan Goster. 1348.

[فردوسى، ابوالقاسم. شاهنامه، مشهر، سخن گستر،

$[.1 \%$ is

[27] Behazin D. Ardabil (what do I know from Iran?), Tehran: deftere pezhohesh hayeh farhangi.1382.

[بهآذين، داريوش. اردبيل (از ايران خه ميدانم؟). تهران:

دفتر يزوهش هاى فرهنگ

[28] Mustawfī Q, H $\square$ amdAllah Ibn Abī Bakr ibn $A h \square$ mad. Nuzhat-al-qulub, translated by Moh $\square$ ammad Dabir Siyāqi, Tehran: ketabkhane Tahury.1336.

[مستوفى قزوينى، حمداللّبن ابى بكربن احمد. (عسبا). نزهألقلوب. به كوشش محمّد دبير سياقى، تهرئ تهران:

كتابخانه طهورى.]

[29] Stevens R. The land of the great Sophy. London: Methuen; 1962.

[30] Yaghout H, Shahab al-din Abu Abdulah. Mojem al-boldān, Tehran, Bina.1965; 1.

[ياقوت حموى، شهاب الدين ابوعبداله الحموى الرومى.

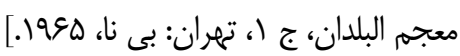

[31] Johansson SA, Campbell JL. PIXE: A novel technique for elemental analysis. 1988.

[32] Nastasi M, Mayer JW, Wang Y. Ion beam analysis: fundamentals and applications. CRC Press; 2014.

[33] Vicenzi EP, Eggins S, Logan A, Wysoczanski R. Microbeam 
characterization of corning archeological reference glasses: new additions to the smithsonian microbeam standard collection. Journal of Research of the National Institute of Standards and technology. 2002; 107(6):719.

[34] Sayre EV, Smith RW. Compositional categories of ancient glass. Science. 1961; 133(3467):1824-6.

[35] Blomme A, Degryse P, Dotsika E, Ignatiadou D, Longinelli A, Silvestri A. Provenance of polychrome and colourless 8th-4th century BC glass from Pieria, Greece: a chemical and isotopic approach. Journal of Archaeological Science. 2017;78:134-46.

[36] Phelps M, Freestone IC, Gorin-Rosen Y, Gratuze B. Natron glass production and supply in the late antique and early medieval Near East: The effect of the Byzantine-Islamic transition. Journal of Archaeological Science. 2016;75:57-71.

[37] Carmona N, Villegas MA, Jiménez P, Navarro J, García-Heras M. Islamic glasses from Al-Andalus. Characterisation of materials from a Murcian workshop (12th century AD, Spain). Journal of Cultural Heritage. 2009;10(3):439-45.

[38] Qin Y, Wang Y, Chen X, Li H, Xu Y, Li $\mathrm{X}$. The research of burning ancient Chinese lead-barium glass by using mineral raw materials. Journal of Cultural Heritage. 2016;21:796-801.

[39] De Bardi M, Hutter H, Schreiner M, Bertoncello R. Potash-lime-silica glass: protection from weathering. Heritage Science. 2015;3(1):1-9.

[40] Zhang B, Cheng HS, Ma B, Li QH, Zhang P, Gan FX, Yang FJ. PIXE and ICP-AES analysis of early glass unearthed from Xinjiang (China). Nuclear Instruments and Methods in Physics Research Section B: Beam Interactions with Materials and Atoms. 2005;240(12):559-64.

[41] Jackson CM, Paynter S, Nenna MD, Degryse P. Glassmaking using natron from el-Barnugi (Egypt); Pliny and the Roman glass industry. Archaeological and Anthropological Sciences. 2018;10(5):1179-91.

[42] Henderson J, An J, Ma H. The archaeometry and archaeology of ancient Chinese glass: a review. Archaeometry.
2018;60(1):88-104.

[43] Rosenow D, Meek A, Phelps M, Freestone I. Things that travelledMediterranean Glass in the First Millennium CE. UCL Press; 2018.

[44] Topić N, Radović IB, Fazinić S, Šmit Ž, Sijarić M, Gudelj L, Burić T. Compositional analysis of Late Medieval glass from the western Balkan and eastern Adriatic hinterland. Archaeological and Anthropological Sciences. 2019; 11(5):2347-65.

[45] Fiorentino S, Venezia B, Schibille N, Vandini M. Streams across the Silk Roads? The case of Islamic glass from Ghazni. Journal of Archaeological Science: Reports. 2019; 25:153-70.

[46] Shortland AJ, Kirk S, Eremin K, Degryse P, Walton M. The Analysis of Late Bronze Age Glass from Nuzi and the Question of the Origin of Glass-Making. Archaeometry. 2018 Aug;60(4):764-83.

[47] Machado A, Wolf S, Alves LC, KatonaSerneels I, Serneels V, Trümpler S, Vilarigues M. Swiss stained-glass panels: an analytical study. Microscopy and Microanalysis. 2017; 23(4):878-90.

[48] Schibille N, Sterrett-Krause A, Freestone IC. Glass groups, glass supply and recycling in late Roman Carthage. Archaeological and Anthropological Sciences. 2017 Sep; 9(6):1223-41.

[49] Van Wersch L, Loisel C, Mathis F, Strivay D, Bully S. Analyses of early medieval stained window glass from the monastery of Baume-Les-Messieurs (Jura, France). Archaeometry. 2016; 58(6):93046.

[50] Silvestri A, Tonietto S, Molin G, Guerriero P. The palaeo-Christian glass mosaic of St. Prosdocimus (Padova, Italy): archaeometric characterisation of tesserae with copper-or tin-based opacifiers. Journal of archaeological science. 2014; 42:51-67.

[51] Vataj E, Hobdari E, Röhrs S, Vandenabele P, Civici N. Analytical characterization of glass tesserae from mosaics of early Christian basilicas in Albania. Applied Physics A. 2017;123(1):1-5.

[52] Henderson J, McLoughlin SD, McPhail DS. Radical changes in Islamic glass technology: evidence for conservatism 
and experimentation with new glass recipes from early and middle Islamic Raqqa, Syria. Archaeometry. 2004;46(3):439-68.

[53] Freestone IC, Gorin-Rosen Y, Hughes MJ. Primary glass from Israel and the production of glass in late antiquity and the early Islamic period. MOM Éditions. 2000;33(1):65-83

[54] Freestone IC. Composition and affinities of glass from the furnaces on the island site, Tyre. Journal of Glass Studies. 2002; 67-77.

[55] Mirti P, Pace M, Negro Ponzi MM, Aceto M. ICP-MS Analysis of Glass Fragments of Parthian and Sasanian Epoch from Seleucia and Veh Ardaš? R (Central Iraq). Archaeometry. 2008; 50(3):429-50.

[56] Mirti P, Pace M, Malandrino M, Ponzi MN. Sasanian glass from Veh Ardašīr: new evidences by ICP-MS analysis. Journal of Archaeological Science. 2009; 36(4):1061-9.

[57] Wood M, Panighello S, Orsega EF, Robertshaw P, van Elteren JT, Crowther A, Horton M, Boivin N. Zanzibar and Indian Ocean trade in the first millennium CE: the glass bead evidence. Archaeological and Anthropological Sciences. 2017; 9(5):879-901. 